\title{
Headship and Poverty in Africa
}

\section{Caitlin Brown and Dominique van de Walle}

\begin{abstract}
With a little more care to take context and the confounding attributes that make female-headed households (FHHs) particularly prone to poverty into account, this paper argues that headship can be useful for identifying poor households in Africa. Standard welfare comparisons between FHHs and male-headed households (MHHs) have largely ignored two confounding factors: marital status (affecting access to markets and services) and heterogeneity in household demographics (with bearing on economies of scale in consumption). Both influence welfare and are correlated with gender of headship. As judged by the usual per capita welfare measures, FHHs, on average, have lower poverty rates than $\mathrm{MHH}$ in Africa. However, even a modest adjustment for economies of scale in consumption changes the poverty comparisons, with FHHs faring significantly worse overall in East, Central, and Southern Africa. Marital status also matters. The households of female heads are poorer than MHHs except when the female head is married. Taking the head's marital status and the household's demographics into account is critical to the association between female headship and welfare outcomes.
\end{abstract}

Keywords: Female-headed households, gender, poverty, economies of scale, Africa, marital status

JEL: I31, I32, J12, J16

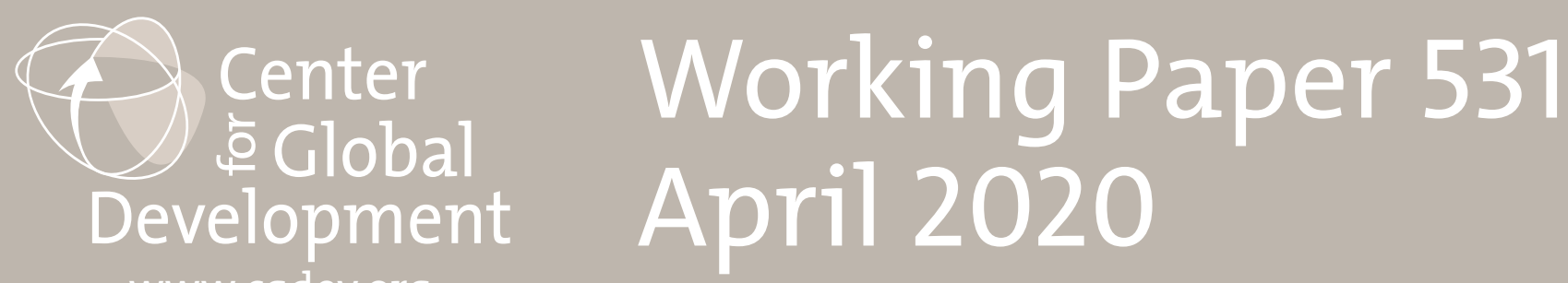




\title{
Headship and Poverty in Africa
}

\author{
Caitlin Brown \\ Central European University \\ Dominique van de Walle \\ Center for Global Development \\ University of Malaya
}

The findings, interpretations and conclusions of the paper are those of the authors, and should not be attributed to the World Bank. Helpful comments were received from Kathleen Beegle, Mayra Buvinic, Sylvie Lambert, Megan O’Donnell, Amber Peterman, Martin Ravallion, Krisztina Szabó, and seminar participants at the annual conference of the Centre for the Study of African Economies, Oxford, 2019.

For funding assistance, Caitlin Brown and Dominique van de Walle are grateful to the World Bank's Strategic Research Program.

Caitlin Brown and Dominique van de Walle, 2020. "Headship and Poverty in Africa." CGD Working Paper 531. Washington, DC: Center for Global Development. https:// www.cgdev.org/publication/headship-and-poverty-africa

Center for Global Development 2055 L Street NW Washington, DC 20036

202.416 .4000

(f) 202.416 .4050

www.cgdev.org
The Center for Global Development works to reduce global poverty and improve lives through innovative economic research that drives better policy and practice by the world's top decision makers. Use and dissemination of this Working Paper is encouraged; however, reproduced copies may not be used for commercial purposes. Further usage is permitted under the terms of the Creative Commons License.

The views expressed in CGD Working Papers are those of the authors and should not be attributed to the board of directors, funders of the Center for Global Development, or the authors' respective organizations. 


\section{Contents}

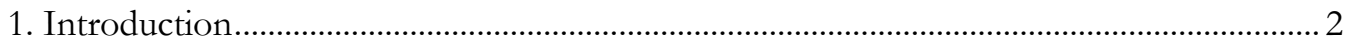

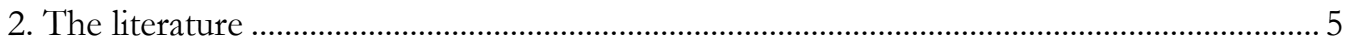

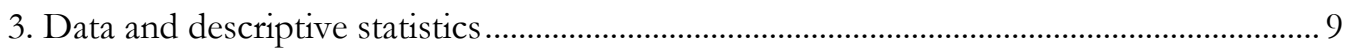

4. Poverty comparisons using household per capita expenditures..........................................12

5. Allowing for economies of scale in consumption and lower costs of children in

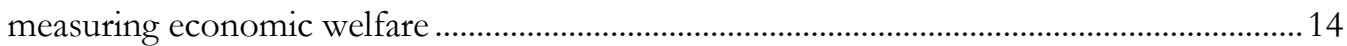

6. Controlling for household demographics and attributes of the head.................................. 16

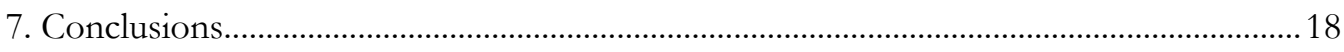

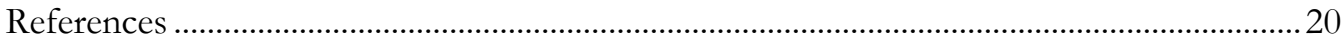




\section{Introduction}

The gender of the household head has been a prominent focal point in two branches of the literature on poverty and development. The first is in the literature on the 'feminization of poverty,' where one often encounters the view that female-headed households (FHHs) are the poorest of the poor. ${ }^{1}$ This has carried weight in policy. Characteristics of household heads, and in particular gender, have frequently been used as proxies for household welfare and for targeting poor households. ${ }^{2}$

The second branch comprises quantitative poverty assessments carried out by both the international development institutions and researchers that compare poverty across maleheaded households (MHHs) and FHHs. Using per capita consumption or income as the indicator of well-being, such studies often report that FHHs are not in fact poorer. More recently World Bank authors (Munoz-Boudet et al. 2018) make a case for stopping the use of the concept of headship completely in poverty analysis, with some even advocating for abandoning questions on headship in household surveys. ${ }^{3}$

This paper asks whether the gender of the household head is a useful lens on householdlevel poverty and for gaining a better understanding of the family. Sub-Saharan Africa (SSA) is an obvious region to focus on for this purpose. Judged by standard poverty measures and regional groupings, SSA is the world's poorest region, with a poverty rate of $41 \%$ in 2015 , which is over four times the global average rate. ${ }^{4}$ Both the prevalence of female headship and the population shares living in such households have been rising in SSA during the last three decades (Milazzo and van de Walle 2017). Recent data indicate that FHHs account for some 23 to 26 percent of the continent's households and 18 to $21 \%$ of its population. ${ }^{5}$

We acknowledge that, on its own, headship does not provide a useful window on individuallevel welfare as needed for investigating gender and intra-household differences in welfare. Poor individuals are often found in non-poor households (Brown et al., 2019). The two approaches — individual and household — are not interchangeable: they have distinctive objectives and aim to answer different questions. Here, we abstract from comparisons within households and focus solely on comparisons between households.

Our main aim is to make poverty comparisons for female- versus MHHs in the SSA context using consistent measurement methods across multiple countries and accounting for the

\footnotetext{
1 See the review and references in Chant $(2003,2008)$.

${ }^{2}$ For example, Grosh et al. (2008) provides an overview of targeting methods in developing countries that use gender of the head. Also see Del Ninno and Mills (2015) and Karlan and Thuysbaert (2019).

3 The proposal is to replace the standard "relationship to head" question with one on relationship to a reference person, who is the first adult listed on the household roster. This approach is now used in some household surveys in developed economies.

4 This is based on the World Bank's PovcalNet data site using the Bank's international poverty line of $\$ 1.90$ a day at 2011 Purchasing Power Parity.

5 The lower percentages are calculated by the authors based on recent consumption surveys (discussed below) for 43 countries and the higher ones are based on the most recent Demographic and Health Surveys for 35 countries (Milazzo and van de Walle 2017).
} 
unique characteristics that make certain types of FHHs vulnerable to poverty, including marital status and demographics. While many of the issues we emphasize have been noted before, our aim is to bring the key points together and document these issues more widely in a systematic, comparable, and consistent way where possible across the entire SSA region.

Considering only the gender of the head is insufficient for informing anti-poverty policy. However, there are predictable features of the African family that result in female headship and are correlated with poverty, with implications for effective policy-making. Intelligent comparisons between FHHs and MHHs that consider both demographic size and composition, as well as the factors leading to household formation, can help to better understand poverty and to devise and target effective anti-poverty policies at the householdlevel.

Whether headship is meaningful as an analytical concept is clearly context specific and we restrict our analysis and conclusions to SSA. The idea of the household head is a familiar and meaningful one in many cultures. In SSA, household members typically have no problem in identifying the head; this is rarely identified as a problem in implementing surveys. African households often have vertically and horizontally complex structures, and differ significantly from Western notions of what constitutes a household. How household members relate to the head and to one another may be vital to understanding various issues of policy relevance. In general, household organization matters to welfare, in particular for intra-household inequality and hence individual poverty. Female headship is one aspect of this.

The ability of FHHs to flourish in gender unequal societies depends critically on why they are female-headed. For both men and women, a change in marital status is a common precursor of headship. For African men, it is almost exclusively marriage. The most common and culturally expected household type in SSA is one with a married male head. Special circumstances underlie cases where an adult male is not perceived as the head. A large share of FHHs are formed as the result of a marital shock - divorce or widowhood. ${ }^{6}$ If, prior to the shock, the husband was the primary bread-winner or the means through which livelihood opportunities and assets were acquired, the newly formed FHH may be much worse off, particularly when it contains dependents. On the other hand, married FHHs who have remitting migrant husbands may have higher standards of living than MHHs who do not have remitting household members. A similar outcome can occur for women with non-resident polygamous husbands or whose education, incomes, or prevailing social mores allow them to choose to live independently as heads of their own households.

Marital status of the head is thus a potentially important confounding factor. We argue that this is a predictable feature of the African family that results in female headship and is correlated with poverty, with implications for (inter alia) social protection and the targeting of anti-poverty programs.

${ }^{6}$ Divorce includes separation or abandonment. In context where a formal divorce accords women certain rights and the ability to remarry, other forms of marital breakup may be far worse for women. 
Such foundational factors result in FHHs tending to be smaller in size and distinctive in their demographic composition. Given their formation process, a majority of FHHs lack a male adult member, such that they are also disproportionately affected by gender-related inequalities and deprivations that face women in the African context. The loss of a male connection to local economic and social institutions can be debilitating to an African household's livelihood. This difference in the demographics of the family-notably in household size-is another potentially important confounding factor when, as is typical, the existence of economies of scale in consumption-whereby two people can live more cheaply together than apart-is not taken into account.

The paper expands upon existing work in several ways. Firstly, we provide a comprehensive empirical study for SSA of the poverty outcomes using the same methods and measurement conventions and nationally representative data across countries covering a large portion of the continent's population. We disaggregate the key indicator of headship to focus on various sub-groups of FHHs and to test whether generalizations become acceptable as well as useful. The poverty of FHHs is compared to that of MHHs in the aggregate and separately by urban/rural sector, by categories of the head's marital status, and by whether the household contains an adult male member.

The analysis begins with the commonly-used household consumption per capita as our benchmark indicator of welfare. Given that FHHs are typically smaller in size, we probe into the robustness of our results to different assumptions about scale economies and household demographic structure. Regression analysis is used to investigate differences in householdlevel poverty measures between FHHs and MHHs further controlling for the head's characteristics, particularly marital status, age, and education.

Across SSA, FHHs are found in aggregate to be better-off than MHHs when household per capita expenditure is used as the living standards indicator. However, we find important variation in the relative welfare of FHHs both within and across sub-regions: for example, while FHHs have consistently lower poverty rates than MHHs in West Africa, the converse is true in Southern Africa.

Explicitly acknowledging FHHs' distinguishing characteristics affects poverty comparisons. Allowing for even modest economies of scale in consumption results in FHHs being worse off on average in East and Central Africa. MHHs retain higher poverty rates on average only in West Africa, although the size of the difference is much diminished. Regressions of per capita consumption reveal that once controls for household size are added, female headship is associated with significantly lower average expenditures. Demographic composition has little additional impact. A further highly relevant correlate of poverty is the head's marital status: among households with married heads, those with a female head are found to have lower poverty rates, while FHHs with heads in all other marital status categories are worse off than MHHs. Importantly, the latter account for 80 percent of all female heads.

The next section discusses the relevant literature. Section 3 describes the data and what they tell us about the current prevalence and characteristics of FHHs. Section 4 turns to poverty comparisons between FHHs and MHHs using household per capita expenditures, the most 
commonly used welfare indicator for such comparisons. Section 5 investigates how alternative assumptions about scale economies affect the results, while Section 6 examines how allowing for the heterogeneity among FHHs further elucidates poverty comparisons. Section 7 concludes.

\section{The literature}

Concerned about gendered poverty but lacking data on individual living standards, policymakers and analysts have long focused on the gender of the household head as a way to overcome the data problem. In many assessments of poverty for developing countries, this may be the only way gender is considered. An extensive literature debates whether FHHs are more economically deprived than MHHs; however, little cross-country consensus has emerged. Some studies argue that FHHs are on average poorer than MHHs (DeGraff and Bilsborrow 1993; Barros et al. 1997; Buvinić and Gupta 1997; Chant 1997b, 2008). Others dispute this finding (Lampietti and Stalker 2000; Quisumbing et al. 2001; MunozBoudet et al. 2018).

Studies that focus on Africa are similarly divided in their conclusions. In South Africa, the evidence of relative disadvantage for FHHs is unambiguous (Rogan 2013; Posel and Rogan 2012). Appleton (1996) finds that FHHs in Uganda are not poorer on average, with households headed by more educated women and recipients of remittances appearing to drive the results. Yet, widow-headed Ugandan households are shown to be the most impoverished. Oginni et al. (2013) argues that FHHs in Nigeria have a lower likelihood of poverty in terms of household wealth. Lampietti and Stalker's review of World Bank poverty assessments finds FHHs to be poorer in 10 of 21 sub-Saharan African country assessments reviewed. Quisumbing et al. (2001) find only FHHs in Ghana to be poorer out of the 10 countries studied (6 of which are in sub-Saharan Africa).

In some quarters, an outcome of the often contradictory results has been to dismiss the gender of head as not useful for poverty comparisons. Yet, insufficient attention has typically been paid to how such welfare comparisons across demographic groups are made. This paper contends that with a little more care to take context and the confounding attributes that make FHHs particularly prone to poverty into account, headship can be useful for identifying poor households.

Prominent among the defining attributes of FHHs, which ignored, can yield inconsistent comparisons with $\mathrm{MHHs}$, are household size and demographic composition. Demographics typically do not favor FHHs, who tend to have fewer working age adults and higher dependency ratios. Women heads are frequently the household's sole caregiver and earner. Consequently, they can be expected to face a disproportionate work burden and pronounced time poverty (Buvinic and Gupta 1997; Quisumbing et al. 2001). In South Africa, Rogan (2013) argues that much of the disadvantage faced stems from a relative lack of economically active male adults, the generally lower earnings of women if they find work, and higher dependency ratios. 
The demographic differences between male- and female-headed households have implications for how poverty should be assessed for these households. Indeed, the use of non-comparable measures of living standards and/or benchmarks for judging deprivation partly accounts for the lack of consensus concerning the relative well-being of FHHs. ${ }^{7}$ Given that FHHs have fewer household members on average, per capita poverty measures tend to understate their poverty and overstate that of (on average larger) MHHs, given economies of scale in consumption. A number of studies show that making allowance for scale economies reverses conclusions about the poverty comparison (Lanjouw and Ravallion 1995, Drèze and Srinivasan 1997, for India; Fuwa 2000, for Panama; van de Walle 2013, for Mali). The different demographic composition of FHHs may also affect poverty comparisons. The latter can be corrected to account for the different consumption needs of adults and children by using adult equivalent scale-adjusted poverty measures. This paper compares poverty rates between FHHs and MHHs using both standard per-capita-based measures as well as measures adjusted for potential scale economies in consumption and adult equivalent scales.

FHHs are a heterogeneous group both within and across geographic areas. A large share is formed as the result of a marital shock that is likely to be much more economically catastrophic for women than for men in SSA. The vast majority of African men spend their adult lives married: while $80 \%$ of men in their early 80 s remain married, by that age over $80 \%$ of women are widows (Djuikom and van de Walle 2018). Remarriage after divorce and widowhood is significantly lower for women, although West Africa is an exception.

In combination with household demographic composition, the head's marital status is thus likely to be essential for determining outcomes for FHHs. Given that men are frequently the gatekeepers of women's access to legal rights and productive assets such as land, and together with the well-documented legal and socio-economic handicaps women face relative to men in African societies, marriage dissolution is often more calamitous for women.

Indeed, households headed by widows, divorced or separated, and never married women are frequently found to be disadvantaged compared to their male-headed counterparts; see, for example, Horrell and Krishnan (2007), van de Walle (2013), and Djuikom and van de Walle (2018). ${ }^{8}$

Against that, some FHHs may have greater access to transfers and remittances from nonresident family members; for example, migrant husbands or sons. FHHs who receive transfers from a male member are consistently found to be as well-off (in terms of consumption or income) as MHHs, and substantially better off than other FHHs (Buvinić and Gupta 1997; Lampietti and Stalker 2000; Horrell and Krishnan 2007). However, not all married female heads receive contributions from migrant partners. Facing all the constraints that are inherent in their gender, they can be among the poorest (Kennedy and Haddad

\footnotetext{
7 The sensitivity of results to methods is reasonably well-recognized in the academic literature (Louat, van der Gaag, and Grosh 1993; Haddad et al. 1996; Quisumbing et al. 2001).

8 Similar results are found for Bangladesh (Joshi 2005); India (Drèze and Srinivasan 1997) and Vietnam (Klasen et al. 2015).
} 
(1994) for Kenya). In some of the predominantly Muslim countries in West Africa, a share of polygamous wives head their own households while being financially supported by a nonco-resident husband. Finally, some FHHs with married heads have a residing male adult who is often disabled or chronically ill. Although increasing the functional dependency ratio, the presence of a male adult in such cases may nonetheless allow better access to legal rights and productive assets. In evaluating the welfare of FHHs, it is therefore crucial to account for the specific process of family formation and dissolution that originated the household (Haddad et al. 1996; Joshi 2005).

Regional context, reflecting local socio-economic norms and institutions, is also important. Much of the existing literature has focused on outcomes for FHHs in one particular country, region, or cluster of villages. Yet, we might expect the welfare associated with different types of FHHs to vary across countries and even regions. For example, in some countries, notably, predominantly Muslim cultures, remarriage after divorce and widowhood is encouraged and aided by custom. In others, remarriage is discouraged, and widows and divorcees are ostracized and discriminated against (Sossou 2002; Peterman 2012; Milazzo and van de Walle forthcoming).

Inheritance and legal systems accord women few rights other than through their fathers and husbands, or other male relatives. As has been emphasized for Africa, women access resources and visibility through marriage (Fafchamps and Quisumbing 2002, 2005a, 2005b; Kevane 2004). Gender inequalities may be vastly exacerbated upon the loss of a male adult - usually a husband. For example, following widowhood or divorce, women often lose economic support and protection, including labor assistance, labor earnings, access to land and other productive inputs that are conditional on marriage, and sometimes housing (Gray and Kevane 1999; Torkelsson 2007). The well-being of FHHs is thus likely to vary across countries according to the degree to which women are discriminated against in their access to education, land, and credit, and stigmatized due to cultural norms and violence.

FHHs, and in particular those without a resident male adult, may also face differences in their access to productive assets. Considerable gender inequalities have been documented by an enormous body of scholarly work for Africa. Relative to men, African women tend to have lower human capital endowments, lower earnings, less command over public goods and services, fewer political and legal rights, and more stringent constraints on mobility and socially acceptable activities (Kevane 2004; Djuikom and van de Walle 2018). One might readily expect that as heads, women will have a harder time supporting their households' livelihoods and be less resilient to household-level shocks.

One consequence of higher dependency ratios and fewer working-age adults in FHHs is that agricultural production becomes harder. The main source of livelihoods in rural Africa continues to be farming, with women constituting approximately $40 \%$ of the agricultural labor force (Palacios-Lopez et al. 2017). FHHs are found on average to have fewer productive assets including land and livestock and lower access to extension services, and to be less likely to adopt new technologies (Doss 2001; Doss and Morris 2001; Tiruneh et al. 
2001; Chirwa 2005; Torkelsson and Tassew 2008; Croppenselt et al. 2013; Ragasa et al. 2013; Ndiritu et al. 2014; Doss et al. 2015).

Furthermore, a literature has found that female-owned or female-managed plots are less productive than those owned or managed by men (Udry et al. 1995; Udry 1996; Peterman et al. 2011). Several studies conclude that lower levels of inputs and resource endowments explain the disadvantage associated with female farmers (Quisumbing 1996; Peterman et al. 2010; Ali et al. 2016). Bezabih and Holden (2006) and Holden and Bezabih (2008) argue that women plot owners in Ethiopia (all of whom reside in FHHs) have lower productivity in part because they must rent out the land due to insufficient access to labor. Weak bargaining power in the land lease market hinders female owners' ability to screen tenants, enforce contracts, and frequently forces them to rent to relatives who are inefficient land-users. Goldstein and Udry (2008) links the lower productivity of land farmed by women in Ghana to fewer fallow periods. The latter are connected to insecure land rights that are associated with women's less central role in village social and political networks.

Studies using detailed information on agricultural plot-level data demonstrate that the gender differentials in plot productivity are attributable to inferior inputs, specifically in regards to land and crop cultivation, as well as to lower returns to endowments for women farmers (Aguilar et al. 2015; Kilic et al. 2015; Oseni et al. 2015; Slavchevska 2015; De La O Campos et al. 2016; Marenya et al. 2017; O’Sullivan et al. 2014). These studies also highlight the lack of access female plot managers have to household male labor, relative to male plot owners. Aguilar et al. (2015), for example, finds that the productivity gap between male and female plot managers is driven primarily by non-married women, while Kilic et al. (2015) and Slavchevska (2015) show that the use of household adult male labor inputs is key in explaining much of the difference.

Where studies have been able to compare productivity between male and female farmers, while making the distinction between female managed plots in MHHs versus those in FHHs, it has been clear that female farmers in FHHs do far worse than those in $\mathrm{MHHs}$ (Croppenstedt et al. 2013). Torkelsson and Tassew (2008) show that women in MHHs in Ethiopia have greater access to land, labor, and financial resources relative to women who head their own households. Some evidence points to greater constraints for rural households not containing a male adult (Kossoudji and Mueller 1983; Croppenstedt et al. 2013). However, the presence of a male adult may be a constraint in itself: in the admittedly different context of urban South Africa, Posel (2001), for example, finds that only $20 \%$ of male adults in FHHs were employed, and that FHHs with unemployed male adults were much more likely to be found in the bottom of the expenditure distribution. This paper aims to understand these issues further by disaggregating FHHs where possible by the presence of male adults.

A further issue in the literature regards the different definitions of headship across studies and how best to define it (Rosenhouse 1989; Handa 1994; Kishor and Neitzel 1996; Ayad et al. 1997; Bruce and Lloyd 1997; Buvinic and Gupta 1997; Chant 1997a, 1997b, 2008;

Quisumbing et al. 2001; Milazzo and van de Walle 2017). Surveys typically define the head 
quite loosely as the member who is "considered responsible" for the household and ask respondents to define this person. Household members are then categorized by their relation to this individual. Note that delineating a head is a separate issue from choosing survey respondents who should be the household members who are most knowledgeable on each specific subject.

In trying to devise better ways of studying female headship, studies have aimed to redefine headship to match their aims. One view is that it should be economic based and focus on the individual bringing the most economic resources into the household. This has drawbacks, including that it requires strong assumptions and that data do not typically allow for its implementation. Most pertinently, the value of women's non-market work and contributions to the household's care and resources are habitually left unmeasured in standard surveys.

Survey-reported headship status may not be consistently defined across or even within countries since it is at the discretion of survey respondents. However, this is equally true of many routinely collected variables such as labor status, years of education, age, household size, religion, marital status, etc., that nonetheless prove to be useful in analysis. What is important is that household members themselves judge an individual to be the agreed head. Why they do so is likely to be quite subjective, but nevertheless offers valuable information which may be crucial to understanding household dynamics and welfare. Furthermore, in rigidly male-dominant societies, and/or in places, such as SSA, where polygamy is widespread and/or multiple generations live together, knowing who is identified as head and understanding household organization can be essential to understanding intra-household allocation and other outcomes.

\section{Data and descriptive statistics}

We use the latest available, nationally representative, household consumption surveys for as many African countries as possible. These are drawn from two key sources. For poverty comparisons, the primary source is the World Bank's PovcalNet database of harmonized consumption surveys, collected between 2004 and 2014, covering 43 countries and accounting for some $84 \%$ of Africa's current population. ${ }^{9}$ Table A1 in our online Appendix lists countries and survey years. The consumption data are converted to real (country CPI adjusted) 2011 PPP. Our base poverty calculations use consumption per capita as the welfare indicator and the World Bank's international poverty line of \$1.90 at 2011 PPP (Ferreira et al. 2016). ${ }^{10}$

As the harmonized database contains a limited set of variables, we also briefly draw on the World Bank's (at the time of writing) most recent Living Standards and Measurement Study (LSMS-ISA) household-level consumption surveys. These cover 9 countries — five in West

\footnotetext{
${ }^{9}$ The database was compiled by the World Bank for the purpose of making poverty comparisons across countries.

10 This line updates the $\$ 1.25$ a day line set by Ravallion et. al (2009).
} 
and four in East Africa for years ranging from 2009 to 2014.11,12 We use these data to examine the receipt of remittances and the sensitivity of our results to more detailed data on demographics.

We rely on survey-reported headship to determine whether a household is female- or maleheaded. Our judgement is that it is preferable to rely on the views of members of the households themselves rather than to impose our own. While we report findings at the country-level and account for potential differences in how households define headship between countries where possible, we acknowledge that our results may hide cultural and other differences in how headship is reported. ${ }^{13}$

Using the PovcalNet database, Table 1 shows the prevalence of FHHs and shares of the population living in FHHs by country and across sub-regions, as well as by urban and rural areas. Overall, $23 \%$ of households are headed by women, accounting for $18 \%$ of SSA's population. There is pronounced variability across regions: Southern Africa has the highest proportion with $43 \%$ of its population residing in FHHs, and West Africa the lowest with $13 \%$. On average, a larger share of households is female-headed in urban than in rural areas, at $26 \%$ and $22 \%$ respectively. This holds across all regions (and most countries) with the exception of Southern Africa, where women head a larger share of rural households (49\% versus $35 \%$ ). These numbers are generally consistent with counts from the Demographic and Health Surveys (Milazzo and van de Walle 2017).

Given that FHHs are often formed as a result of a marital dissolution, and that remarriage rates for widows and divorcees are typically lower for women, one expects clear differences in the marital status of male and female heads. Table 2 shows the prevalence of FHHs by categories defined according to the head's marital status. An overwhelming majority of heads who are divorced or widowed are female ( $71 \%$ and $85 \%$ respectively on average). In contrast, only a small share of married heads is female, with the proportion being larger for those married polygamously than monogamously (19\% and 6\% respectively), reflecting the fact that in some countries it is common for one or more wives to live separately from their polygynous husbands.

Marital status is unevenly distributed across heads by gender (Table A3). While $83 \%$ of male heads are married, this is true only for $24 \%$ of female heads; most of the difference is made up of widows and divorcees which describes $64 \%$ of female but only $4 \%$ of male heads. About the same share is never married ( $8 \%$ of female and $7 \%$ of male heads); and $4 \%$ and $5 \%$, respectively, report living together in an informal union with a partner. In all cases, these averages hide substantial heterogeneity across countries and genders.

\footnotetext{
11 Table A2 in the Appendix lists countries and survey dates.

12 As both the prevalence and attributes of female headship tend to vary across regions, these data cannot be used to draw Africa-wide conclusions; rather, we use them to explore aspects not adequately covered in the larger database.

13 A related issue is how households are defined. Beaman and Dillon (2012) shows that slight variations in definitions significantly affect both size and composition. Here, households are as defined by the surveys.
} 
The striking differences in marital status are suggestive of large demographic differences between the two household groups. Tables 3 and 4 provide descriptive statistics for key attributes related to the head and demographic composition for rural and urban households, as well as for FHHs with and without an adult (defined as 18 and older) male member using the PovcalNet dataset and the LSMS-ISA surveys, respectively. ${ }^{14}$ As noted in the previous section, the presence of a male adult can have substantial implications for the well-being of FHHs; for example, men of working age may be better able to access more remunerative and better outside employment than women; they can help on the family farm or enterprise or simply provide better connections to economic livelihoods. Alternatively, the absence of a male adult may indicate that a female head has a remitting migrant husband.

Table 3 reveals that across the continent, a majority of FHHs - 69\% in rural and $64 \%$ in urban areas - do not contain a resident male adult. Across regions, this ranges from 54\% to $76 \%$ for rural FHHs in Southern and Central Africa respectively. Overall, female heads tend to be older, less educated, and to head significantly smaller households $(3.9$ members for FHHs versus 5.4 for MHHs in rural areas and 4.6 versus 3.8 members in urban areas) with higher dependency ratios, ${ }^{15}$ with the gap in attributes typically smaller in urban than in rural areas. Among them, those with a male adult member are also headed by older women who are more likely to be widowed but less likely to be divorced. In addition, they are significantly larger in size but have lower dependency ratios relative to those without an adult male. This holds across sectors and most regions.

Using the LSMS data, which contains variables not in the Povcalnet data, Table 4 provides more detail on household composition, although for far fewer countries. ${ }^{16} \mathrm{FHHs}$ are found to have larger proportions of female members (and in particular, older ones). As seen before, those without a male adult are substantially smaller in size than those with a male adult (roughly 3 household members versus 5). Importantly, this translates into the highest dependency ratio for the former (1.5 in rural and 1.0 in urban areas) and the lowest for the latter (0.79 in rural and 0.56 in urban), with MHHs somewhere in between (1.17). FHHs are also far less likely to contain a working male adult and are more likely to contain potentially disadvantaged members, such as widows (present in almost $60 \%$ of $\mathrm{FHHs}$ in rural areas and more than $40 \%$ in urban areas), or disabled adults (and in particular, disabled female adults who are present in roughly $13 \%$ and $10 \%$ of rural and urban households respectively). Overall, $15 \%$ and $12 \%$ of FHHs in rural and urban areas, respectively, have at least one disabled household member versus $10 \%$ and $9 \%$ for MHHs.

Practically all male heads (93\% in rural and $82 \%$ in urban areas) live with a spouse, while this is the case for relatively few FHHs (6\% of all FHHs in rural areas, and 5\% in urban areas).

\footnotetext{
${ }^{14}$ Note that due to the different samples, means vary between the Tables 3 and 4 . Table A5 gives average values for the same variables as in Table 3 by region.

15 Dependency ratios here are defined as the ratio of household members 14 years and younger or 65 years and over to household members between 15 and 64. We use pre-defined age group categories available in the

Povcalnet data and acknowledge that this may underestimate the true ratio if children remain dependent longer or some adults younger than 64 are unable to work.

${ }_{16}$ Table A6 in the Appendix presents the same statistics by marital status for FHHs.
} 
Female heads are also less likely to co-habit with other relatives, such as sons or daughters: $76 \%$ of MHHs in rural areas include the son of the head while only $50 \%$ of FHHs do (and only $30 \%$ of FHHs without a male adult). Interestingly, among FHHs, around $77 \%$ of those with an adult male contain the head's son (and 53\% contain the head's daughter), while this is true for only $28 \%$ (and $41 \%$ for the head's daughter) of FHHs without a male adult.

Finally, the LSMS data also provide some insights on the receipt of remittances across households. Table 5 considers how access to remittances varies by the head's gender and marital status for rural and urban households, as well as how the presence of a male adult among FHHs matters. FHHs, whether their heads are married or unmarried (never or formerly married), are significantly more likely to be recipients of remittances than are MHHs. Among them, we see that those with married heads and no resident male adult are most likely to receive remittances, while married heads co-habiting with a male adult in urban areas are the least likely to do so.

\section{Poverty comparisons using household per capita expenditures}

We begin by calculating Foster-Greer-Thorbecke (FGT) poverty measures using per capita

household consumption (Foster et al. 1984). For country $j$, the FGT measures are given by:

$$
P_{\alpha, j}=\frac{1}{n_{j}} \sum_{\forall i \text { with } y_{i j} \leq z}\left(\frac{z-y_{i j}}{z}\right)^{\alpha}(\alpha=0,1,2)
$$

where $y_{i j}$ is per capita expenditures for household $i$ in country $j, z$ is the poverty line, and $n_{j}$ the total number of households. For $\alpha=0$, the poverty measure is the headcount index $\left(q_{j} / n_{j}\right.$ where $q_{j}$ is the number of households for which $\left.y_{i j} \leq z\right)$, and $\alpha=1$ and $\alpha=2$ give the poverty gap and squared poverty gap indices, respectively. ${ }^{17}$

Table 6 provides the three poverty measures for female- and male-headed households by country and subregions, along with the differences between them (FHH minus $\mathrm{MHH}$, so that a positive value indicates a higher poverty rate for FHHs). In the aggregate, Africa's FHHs have a lower incidence of poverty across all three FGT measures based on per capita expenditures as the living standards indicator. This is true across all regions except Southern Africa, where FHHs are significantly poorer than their male counterparts. ${ }^{18}$ There are some pronounced differences within regions: in East Africa, Ethiopian MHHs are significantly poorer, while the converse is true for Kenya, Malawi, and Mauritius. Within West Africa, MHHs are poorer in every country excluding Cabo Verde, and statistically significantly so in most.

\footnotetext{
${ }_{17}$ Higher values for $\alpha$ place greater emphasis on the incomes of the poorest among the poor (Foster et al. 1984).

18 This accords with earlier findings by Rogan (2013) and Posel and Rogan (2012).
} 
We also consider differences in poverty rates (FHH minus MHH) by the head's marital status, rural-urban location and whether a FHH comprises a male adult member (Table 7; Table A7 in the Appendix provides results by country). ${ }^{19}$ As seen earlier, despite some important sub-regional exceptions, MHHs are poorer than FHHs overall with headcount indices that are 7.9 and 3.3 percentage points higher in continent-wide rural and urban areas, respectively. However, this conclusion is more nuanced when we disaggregate households by the head's marital status. Among those with never-married, divorced or widowed heads, FHHs (accounting for $75 \%$ of all FHHs), have a significantly higher incidence of poverty than their male counterparts. Indeed, the only marital status group for which households headed by men fare worse is that of married heads. ${ }^{20}$ The same is found across sectors and regions (though the gender differences for never married, divorced and widowed heads are statistically insignificant on average for rural West Africa and for the never-married in urban Southern Africa).

As discussed in Section 5, households headed by married men are also likely to be larger and to thus have their poverty exaggerated by the per capita welfare indicator if there are economies of scale in consumption. As the vast majority of male heads are married, we compare FHHs by their head's marital status with MHHs taken as one group, and show that MHHs are poorer with the one exception of households headed by divorced or widowed female heads in East, Central and Southern Africa (Table 7, panel 2).

Poverty rates among FHHs by the head's marital status and the presence of a male adult are given in the bottom panel of Table 7. The numbers represent FHHs with a male adult minus FHHs without a male adult differences in the headcount indices. Across almost all regions, sectors, and marital status categories, FHHs with no male adult have higher poverty rates. This result may well in part reflect the use of per capita consumption and the fact that these are on average smaller households.

Among FHHs, those with married heads have significantly lower poverty rates than those with divorced or widowed heads, but higher poverty rates than households with never married heads (accounting for $8 \%$ of all FHHs) (Table A8). The latter are likely to include better educated and economically independent women who have chosen to delay marriage, and as a result, have smaller-sized households: $40 \%$ (17\%) of never-married heads have at least secondary education and 2.8 (3.7) household members on average in urban (rural) areas.

Poverty rates between the different types of households are also likely to differ over the lifecycle of the head. Figure 1 plots poverty rates for households with married and unmarried female heads with and without an adult male, with all MHHs included as a benchmark. Among households with young heads across regions, married FHHs with a male adult have the highest poverty rates - in Central Africa this continues to be the case up to heads aged

\footnotetext{
${ }^{19}$ Comparisons between FHHs and MHHs within marital status categories are qualitatively similar when using the poverty gap or squared poverty gap index.

${ }^{20} \mathrm{MHHs}$ with heads in informal unions (i.e., living with a partner) in rural areas have higher poverty rates than their female-headed counterparts; in urban areas there is no significant difference overall.
} 
55, while in West Africa, poverty rates for MHHs overtake them from age 25 onwards (and the lowest in Southern Africa). The differences between the households appear to converge as heads age in East Africa, yet they increase in Southern and West Africa. Notably, there seems to be no clear pattern to how the welfare of these categories of FHHs evolve relative to both each other and to MHHs as the head ages. Age, of course, is highly correlated with household demographics. As we will see in Section 6, once one takes into account household size and composition, the head's age has little independent impact on household-level poverty.

\section{Allowing for economies of scale in consumption and lower costs of children in measuring economic welfare}

In the previous section, we found that on average, FHHs have lower poverty rates than MHHs when one uses per capita consumption as the welfare indicator, and that this seems to be in part driven by households with a married female head. However, it is also the case that FHHs are smaller, with fewer children but higher dependency ratios on average (see Tables 3 and 4). As long as two or more people can live more cheaply together than apart that is, there is some scale economy in consumption - a welfare measure based on per capita consumption will tend to overestimate the poverty of larger households. Similarly, if children need relatively fewer resources than adults, per capita scales will overestimate the poverty of households with more children. Here, we test the sensitivity of our results to how household size and lower child costs are accounted for.

Generally, we can rescale consumption to allow for economies of scale in consumption and lower costs of children using equivalized consumption per single adult, as measured by:

$$
y_{i}^{e}(\delta, \theta) \equiv \frac{y_{i}}{\left(n_{a i}+\delta n_{c i}\right)^{\theta}}
$$

where $n_{a i}$ is the number of adults and $n_{c i}$ is the number of children in household $i$ in a particular country; $\delta$ represents adult equivalence of children, where $\delta \in(0,1]$, and $\theta$ represents economies of scale in consumption, where $\theta \in(0,1]$. Following Ravallion (2015), we also rescale the poverty line:

$$
z(\delta, \theta)=\frac{z(1)\left(\bar{n}_{a r}+\delta \bar{n}_{c r}\right)^{\theta}}{\bar{n}_{r}}
$$

where $\bar{n}_{a r}$ and $\bar{n}_{c r}$ are fixed reference values of the numbers of adults and children respectively, with $\bar{n}_{r}=\bar{n}_{a r}+\bar{n}_{c r}$, and $z(1)$ is the per capita poverty line. The reference values are taken to be the country-specific sample means of the two demographic variables. For given $\delta$ and $\theta$, households with $y_{i}^{e}(\delta, \theta)$ less than or equal to $z(\delta, \theta)$ are considered poor. Note that a lower $\theta$ puts a higher weight on economies of scale: at one extreme, setting $\theta=1$ (e.g. household size) assumes that all goods are strictly private, while at the other extreme $\theta=0$ assumes that consumption goods are fully public such that an additional household member does not deplete resources for others. On setting $\theta=0.5$ 
(with $\delta=1$ ) we obtain the "square-root scale" that is used by the OECD (2011) among others. For households with the same per capita expenditure, the lower the $\theta$, the better-off larger households will appear to be relative to smaller households.

The difficulty is in agreeing to what equivalence scale is acceptable. ${ }^{21}$ For example, the use of an adult equivalent scale implies knowledge of the consumption needs of different household members (usually based on actual consumption data from household surveys), which may differ significantly across countries and not accurately reflect actual biological needs (Quisumbing et al. 2001). To avoid somewhat arbitrary decisions about $\delta$ and $\theta$, we consider how poverty rates for MHHs and FHHs contrast for the whole range of possible values. For simplicity, and to isolate each effect separately, we only vary one parameter at a time. Figure 2 displays the results for changes in the weight put on economies of scale by sub-region; an equivalent figure for changes in the adult equivalent scale is found in Figure A1 in the Appendix. ${ }^{22}$

For East and Central Africa, a value of $\theta$ only slightly below one leads to a reversal of the poverty ranking with higher average poverty rates for FHHs. In Southern Africa, the finding that FHHs are poorer is robust to any choice of $\theta$. The $\theta$ at which FHHs have a higher rate of poverty than MHHs varies by region, from 0.95 in East Africa to 0.15 in West Africa. In other words, perceptions about male- versus female-headed household poverty comparisons are highly susceptible to assumptions about how household size is treated. Only a modest emphasis on economies of scale is needed in East and Central Africa for FHHs to be proclaimed poorer than MHHs; conversely, in West Africa, economies of scale need to be very large for the comparison to be reversed.

The differences in household welfare generated by accounting for economies of scale are apparent across the expenditure distribution. The first column of Figure 3 shows the CDFs for average (unscaled) monthly per capita expenditure for MHHs and FHHs; the international poverty line is given by the vertical line. For West and Central Africa, FHHs first-order dominate up to the international poverty line. For East and Southern Africa, the comparison is ambiguous below the poverty line. With $\theta=0.5$ (the square-root scale) the $\mathrm{CDF}$ for FHHs are much closer to those for $\mathrm{MHHs}$ for each of the regions, particularly for households below the poverty line. While MHHs are still poorer on average than FHHs up to the poverty line, this seems to be driven primarily by West Africa. A key takeaway here is that economies of scale substantially affect poverty comparisons between male- and femaleheaded households. Any honest attempt to compare households by headship cannot simply ignore them.

21 There is a deep identification problem in inferring scale parameters from observed market behavior, as explained in Pollak and Wales (1979) and Browning (1992). Here we keep the parameter choice open and test robustness over a wide range of admissible values.

${ }^{22}$ See Appendix Tables A9 and A10 for differences in poverty rates for values of $\theta$ and $\delta$ respectively in increments of 0.1 by country. 
For adult equivalent scales, we see significantly less of an impact: in Southern, Central and West Africa, no possible values of $\delta$ affect the overall poverty comparisons, while in East Africa only an allowance for the lower cost of children of $\delta$ smaller than 0.4 , reverses the global poverty comparison between MHHs and FHHs. By contrast, allowance of even small economies of scale are infinitely more consequential to poverty comparisons between FHHs and MHHs in Africa.

\section{Controlling for household demographics and attributes of the head}

Household size and composition are not the only potentially confounding differences between male- and FFHs, as shown in Tables 3 and 4. We next use regressions to delve more deeply into heterogeneities among households and examine how accounting for demographic composition as well as some key attributes of the head, in addition to household size, alters differences in the welfare indicator and hence poverty comparisons between FHHs and MHHs. We use log household consumption per person as the dependent variable but control for log household size as a regressor. Thus, our regressions are equivalent to using $\ln y_{i}^{e}(1, \theta)$ as the dependent variable (also including log household size as a regressor); all that changes is the interpretation of the coefficient on log household size. ${ }^{23}$

Table 8 shows the estimated coefficients on an indicator for whether a household has a woman at its head from a series of regressions of log household per capita expenditures on all households. The coefficients thus indicate how the per capita consumption of FHHs changes relative to that of $\mathrm{MHH}$ as various household characteristics are successively taken into account. A first regression series compares MHHs to all FHHs, while the second distinguishes between FHHs containing a male adult or not.

Unconditionally and taken as a group, Africa's FHHs have 10 percent higher per capita expenditures on average than MHHs in rural areas. Once country fixed effects are added such that comparisons are strictly within country, the disparity drops to 4 percent underlining the fact that the 43 countries in the database have varying levels of living, social norms, religions, geographic diversity and so on. That heterogeneity is likely to be highly correlated with the average income, education, and empowerment of women, and relatedly with the heterogeneity among FHHs across countries. For example, FHHs by choice are more likely to form and to be more numerous in richer countries. This will tend to bring up the consumption of FHHs.

Controlling next for the household's size radically reverses this picture to a highly significant 13 percent deficit for FHHs compared to the finding above of a 4 percent within country

${ }^{23}$ Noting that we can re-write the regression $\ln y_{i j}^{e}(\theta)=\beta \ln n_{i j}+\varepsilon_{i j}$ as $\ln \left(y_{i j} / n_{i j}\right)=(\beta+\theta-$ 1) $\ln n_{i j}+\varepsilon_{i j}$. 
advantage on average. For urban areas, FHHs are deemed to have lower per capita consumption than MHHs unconditionally (the difference is 3 percent), a gap that rises to 17 percent with country fixed effects and controlling for household size. These results further emphasize the importance of accounting for economies of scale when making comparisons between households with male versus female heads, as discussed in Section 5. The regression coefficient on $\log$ household size hovers around -0.40 for both urban and rural areas which translates into a $\theta$ of at least 0.60 under the identifying assumption that the size of the household matters only via scale economies.

Further adding the household's demographic (age and gender) composition has little effect on the deficit, echoing our above findings regarding the use of adult equivalent scales, while controls for the head's marital status reduce the gap to 8 percentage points favoring MHHs in both rural and urban areas. Widowhood has the most negative effect, reducing per capita expenditures by 12 percent in rural and 11 percent in urban areas. Divorce and never having been married have a somewhat lower dampening effect on living standards, although nonetheless significant, particularly in urban areas. Finally, adding the head's age and education results in a 5 percent deficit in per capita consumption in rural areas, and a 1 percent deficit in urban areas. All these coefficients are statistically significant at over the $1 \%$ level.

The next set of coefficients in Table 8 reveals how the FHH aggregate obscures two quite disparate groups. Unconditionally, in rural areas both FHHs with and without a male adult have higher household per capita consumption expenditures than MHHs, with FHHs with no male faring better than those with a male adult with a per capita consumption gap of 12 percentage points. In urban areas, FHHs with no male also appear to be the best off with a positive gap of 7 percent; however, those with a male adult have substantially lower per capita expenditures (17 percent) than MHHs. In Table 7 we saw that among FHHs, headcount indices based on per capita expenditures were in fact higher for those who did not include a male adult. The apparent discrepancy between the differences in poverty rates reported in Table 7 and the differences in per capita consumption just discussed, is due to the fact that although mean per capita consumption is higher for FHHs with no male (Table 8), inequality among these households is also higher, reflecting a mix of richer households receiving remittances from an absent male and poorer ones headed, say, by elderly widows. This results in higher (unconditional) poverty rates for this group as seen in Table 7.

This overall picture is quite radically altered once country fixed effects are added and differences in household size between the groups are taken into account. As with FHHs as a whole, we find that both FHHs with and without a male adult now have lower per capita expenditures than MHHs (across urban and rural areas). However, the ranking among them has reversed with FHHs with no male faring worse than FHHs with a male adult. Indeed, FHHs with no male adult have roughly 10 percent less on average in terms of per capita expenditures than FHHs with a male adult.

Controlling for demographic composition further explains the gap between the FHHs but increases the difference between FHHs with a male adult and MHHs. Adding controls for 
the head's marital status, age, and education brings the difference between FHHs with no male adult and MHHs to 8 percent in rural and 5 percent in urban areas in favor of MHHs. Interestingly, we find that once we have accounted for all these differences in key attributes, FHHs with a male adult fare better than MHHs in terms of per capita expenditures in both rural ( 2 percent) and urban ( 4 percent) areas.

These results highlight quite dramatically the importance of considering at minimum household size, the presence of a male adult and marital status in determining how FHHs and MHHs compare with respect to living standards in SSA. The head's education also accounts for a significant difference. Comparisons that do not allow for the pronounced disparities in these household attributes are likely to be highly biased if the aim is to obtain welfare-consistent poverty measures.

\section{Conclusions}

A subset of the literature has debated whether headship is a useful variable on which to disaggregate and anchor analysis (Munoz-Boudet et al. 2018). The focus on headship has to some degree been an artifact of available data and poverty measurement practices that are almost exclusively household-level. In the absence of individual-level indicators of welfare, as well as the difficulties associated with collecting such data, analysts interested in gender differentials have used the gender of the head as a proxy. This paper takes the view that using household headship is suitable for some, but not all, questions. Although it is not something we address in the paper, we would suggest that headship is not very useful in studying gender differences in individual welfare per se. In contrast, it can be helpful for examining household welfare differentials. Furthermore, the advantage of such householdlevel comparisons is conditional on taking into account the head's marital status and the household's demographics, both of which are critical to the association between female headship and outcomes.

The paper aims to consolidate existing literature on the welfare of FHHs and provide a nuanced contribution to this debate for sub-Saharan Africa. Our approach emphasizes some key conceptual problems in comparing poverty by headship, specifically the attributes of FHHS that may be expected to specifically disadvantage them.

We confirm that FHHs are a heterogeneous group, with household welfare often a result of how the household was formed. On average, when using household per capita consumption as the welfare indicator as is common, Africa's FHHs have lower poverty rates than MHHs. Yet, even then this is not true across all countries, or regions. Nor is it the case once one relaxes the implausible assumption that there are no scale economies in consumption. Poverty comparisons by gender of headship are extremely sensitive to this widespread assumption which distorts conclusions by exaggerating the poverty of large households and underestimates that of small households. MHHs are significantly larger than FHHS. Accounting for the head's marital status and the demographic composition of households further alters the comparison of well-being. 
We find that FHHs in Southern Africa tend to be poorer than MHHs even when we use per capita consumption. This is likewise true for Central and East Africa once we take into consideration a modest allowance for the economies of scale that larger households face. Across SSA, never-married, divorced, and widowed women in particular head households that are poorer on average than their male-headed counterparts. Married female heads are more likely to receive remittances than $\mathrm{MHHs}$, likely driving the relatively higher standards of living than other types of households.

The presence of a male adult, not common in FHHs (33\% have an adult male), is also shown to be relevant for the well-being of FHHs, but with important heterogeneities and sensitivities to the use of the per capita welfare indicator: FHHs with a male adult who are typically larger fare better on average than the smaller FHHs without a male adult unconditionally. However, this ranking is fully explained and reversed by differences in household size and demographic composition.

While some types of female-headed households are better off than the average male-headed household, many, including those headed by widows or divorcees, are among the poorest. We conclude that in the Africa context, anti-poverty policies concerned with reaching poor and vulnerable households should make use of headship gender in conjunction with the head's marital status and the household's appropriately adjusted demographic size and composition. 


\section{References}

Aguilar, Arturo, Eliana Carranza, Markus Goldstein, Talip Kilic, and Gbemisola Oseni. 2015. "Decomposition of Gender Differentials in Agricultural Productivity in Ethiopia." Agricultural Economics 46(3): 311-334.

Ali, Daniel, Derick Bowen, Klaus Deininger, and Marguerite Duponchel. 2016. "Investigating the Gender Gap in Agricultural Productivity: Evidence from Uganda." World Development 87: 152-170.

Appleton, Simon. 1996. "Women-headed Households and Household Welfare: An Empirical Deconstruction for Uganda.” World Development 24(12): 1811-1827.

Ayad, Mohamed, Bernard Berrère, and James Otto. 1997. "Demographic and Socioeconomic Characteristics of Households.” DHS Comparative Studies No. 26. Calverton, Maryland: Macro International Inc.

Barros, Ricardo, Louise Fox, and Rosane Mendonca. 1997. "Female-headed Households, Poverty, and the Welfare of Children in Urban Brazil." Economic Development and Cultural Change 45(2): 231-257.

Beaman, Lori and Andrew Dillon. 2012. "Do Household Definitions Matter in Survey Design? Results from a Randomized Survey Experiment in Mali." Journal of Development Economics 98: 124-135.

Bezabih Mintewab and Stein Holden. 2006. "Tenure Insecurity, Transaction Costs in the Land Lease Market and their Implications for Gendered Productivity Differentials." 26 th International Conference of the International Association of Agricultural Economists, Brisbane, Australia.

Brown, Caitlin, Martin Ravallion and Dominique van de Walle. 2019. "Are Poor Individuals Mainly Found in Poor Households? Evidence Using Nutrition Data for Africa." Review of Economics and Statistics 101(4): 631-644. https://www.mitpressjournals.org/doi/abs/10.1162/rest_a_00800

Browning, Martin. 1992. "Children and Household Economic Behavior." Journal of Economic Literature 30: 1434-1475.

Bruce, Judith and Cynthia Lloyd. 1997. "Finding the Ties that Bind: Beyond Headship and Household.” In: Haddad, L, Hoddinott, J \& Alderman, H (ed.) Intrahousehold Resource Allocation in Developing Countries: Models, Methods and Policy. International Food Policy Research Institute. Washington, DC: Johns Hopkins University Press. 
Buvinić, Mayra and Geeta Rao Gupta. 1997. "Female-headed Households and Femalemaintained Families: Are They Worth Targeting to Reduce Poverty in Developing Countries?" Economic Development and Cultural Change 45(2): 259-280.

Chant, Sylvia. 1997a. Women-headed Households: Diversity and Dynamics in the Developing World. Palgrave Macmillan, Houndmills, Basingstoke, UK.

Chant, Sylvia. 1997b. "Women-headed Households: Poorest of the Poor? Perspectives from Mexico, Costa Rica and the Philippines." IDS bulletin 28(3): 26-48.

Chant, Sylvia. 2003 "Female Household Headship and the Feminisation of Poverty: Facts, Fictions and Forward Strategies." Gender Institute, Working Paper No. 9 London: London School of Economics.

Chant, Sylvia. 2008. “The 'Feminisation of Poverty' and the 'Feminisation' of Anti-poverty Programmes: Room for Revision?” Journal of Development Studies 44(2): 165-197.

Chirwa, Ephraim. 2005. "Adoption of Fertiliser and Hybrid Seeds by Smallholder Maize Farmers in Southern Malawi." Development Southern Africa 22(1): 1-12.

Croppenstedt, Andre, Markus Goldstein, and Nina Rosas. 2013. "Gender and Agriculture: Inefficiencies, Segregation, and Low Productivity Traps.” World Bank Research Observer 28(1): 79-109.

De la O Campos, Ana Paula, Katia Alejandra Covarrubias, and Alberto Prieto Patron. 2016. "How Does the Choice of the Gender Indicator Affect the Analysis of Gender Differences in Agricultural Productivity? Evidence from Uganda." World Development 77: 17-33.

Del Ninno, Carlo and Bradford Mills (Eds.). 2015. Safety Nets in Africa: Effective Mechanisms to Reach the Poor and Most Vulnerable. The World Bank, Washington D.C.

DeGraff, Deborah and Richard Bilsborrow. 1993. "Female-Headed Households and Family Welfare in Rural Ecuador." Journal of Population Economics 6(4): 317-336.

Djuikom, Marie Albertine and Dominique van de Walle. 2018. "Marital Shocks and Women's Welfare in Africa.” World Bank Policy Research Paper 8306, World Bank, Washington, D.C.

Doss, Cheryl. 2001. "Designing Agricultural Technology for African Women Farmers: Lessons from 25 Years of Experience.” World Development 29(12): 2075-2092.

Doss, Cheryl, Chiara Kovarik, Amber Peterman, Agnes Quisumbing, and Mara Bold. 2015. "Gender Inequalities in Ownership and Control of Land in Africa: Myth and Reality." Agricultural Economics 46(3): 403-434. 
Doss, Cheryl and Michael Morris. 2001. "How Does Gender Affect the Adoption of Agricultural Innovations? The Case of Improved Maize Technology in Ghana." Agricultural Economics 25(1): 27-39.

Drèze, Jean and Srinivasan, P.V. 1997. "Widowhood and Poverty in Rural India: Some Inferences from Household Survey Data.” Journal of Development Economics 54(2): 217-234.

Fafchamps, Marcel and Agnes R. Quisumbing. 2002 "Control and Ownership of Assets Within Rural Ethiopian Households.” Journal of Development Studies 38(6): 47-82.

Fafchamps, Marcel and Agnes Quisumbing. 2005a. "Assets at Marriage in Rural Ethiopia." Journal of Development Economics 77(1): 1-25.

Fafchamps, Marcel and Agnes R. Quisumbing. 2005b. "Marriage, Bequest, and Assortative Matching in Rural Ethiopia." Economic Development and Cultural Change 53(2): 347-380.

Ferreira, Francisco, Shaohua Chen, Andrew Dabalen, Yuri Dikhanov, Nada Hamadeh, Dean Joliffe, Ambar Narayan, Espen Beer Prydz, Ana Revenga, Prem Sangraula, Umar Serajuddin, and Nobu Yoshida. 2016. "A Global Count of the Extreme Poor in 2012: Data Issues, Methodology, and Initial Results.” Journal of Economic Inequality 14: 141-172.

Foster, James, Joel Greer, and Erik Thorbecke. 1984. "A Class of Decomposable Poverty Measures." Econometrica 52: 761-766.

Fuwa, Nobuhiko. 2000. "The Poverty and Heterogeneity Among Female-headed Households Revisited: The Case of Panama.” World Development 28(8): 1515-1542.

Goldstein, Markus and Christopher Udry. 2008. "The Profits of Power: Land Rights and Agricultural Investment in Ghana.” Journal of Political Economy 116(6): 981-1022.

Gray, Leslie and Michael Kevane. 1999. "Diminished Access, Diverted Exclusion: Women and Land Tenure in Sub-Saharan Africa." African Studies Review 42(2): 15-39.

Grosh, Margaret, Ninno, Carlo del, Tesliuc, Emil, Ouerghi, Azedine. 2008. "For Protection and Promotion: The Design and Implementation of Effective Safety Nets." World Bank, Washington DC.

Haddad, Lawrence, Christine Pena, Chizuru Nishida, Agnes Quisumbing, and Alison Slack. 1996. "Food Security and Nutrition Implications of Intrahousehold Bias: A Review of Literature." FCND Discussion Paper 19. Washington, DC: IFPRI.

Handa, Sudhanshu. 1994. "Gender, Headship and Intra-Household Resource Allocation." World Development 22(10): 1535-1547. 
Holden, Stein and Mintewab Bezabih. 2008. "Why is Land Productivity Lower on Land Rented Out by Female Landlords? Theory and Evidence from Ethiopia.” In: Holden, S., Otsuka, K. and Place, F. (eds.) The Emergence of Land Markets in Africa: Assessing the Impacts on Poverty and Efficiency. RFF Press.

Horrell, Sara and Pramila Krishnan. 2007. "Poverty and Productivity in Female-headed Households in Zimbabwe.” Journal of Development Studies 43(8): 1351-1380.

Joshi, Shareen. 2005. Female-Headed-Households in Rural Bangladesh: Incidence, Determinants and Impact on Children's Work and Schooling. Yale University Economic Growth Center Working Paper No. 894.

Karlan, Dean, Thuysbaert, Bram. 2019. Targeting Ultra-Poor Households in Honduras and Peru. World Bank Economic Review 33(1): 63-94.

Kennedy, Eileen and Lawrence Haddad. 1994. "Are Pre-Schoolers from Female-Headed Households Less Malnourished? A Comparative Analysis of Results from Ghana and Kenya." The Journal of Development Studies 30(3): 680-695.

Kevane, Michael. 2004. Women and development in Africa: How gender works. Lynne Rienner Publishers Boulder, CO.

Kilic, Talip, Amparo Palacios-Lopez, and Markus Goldstein. 2015. "Caught in a Productivity Trap: A Distributional Perspective on Gender Differences in Malawian Agriculture." World Development 70: 416-463.

Kishor, Sunita and Katherine Neitzel. 1996. "The Status of Women: Indicators for TwentyFive Countries.” DHS Comparative Studies No. 21. Calverton, Maryand: Macro International Inc.

Klasen, Stephan, Tobias Lechtenfeld, and Felix Povel. 2015. “A Feminization of Vulnerability? Female Headship, Poverty and Vulnerability in Thailand and Vietnam." World Development 71: 36-53.

Kossoudji, Sherrie, and Eva Mueller. 1983. "The Economic and Demographic Status of Female-Headed Households in Rural Botswana." Economic Development and Cultural Change 31(4): 831-859.

Lampietti, Julian and Linda Stalker. 2000. "Consumption Expenditure and Female Poverty: A Review of the Evidence.” Policy Research Report on Gender and Development Working Paper Series No. 11, World Bank.

Lanjouw, Peter and Martin Ravallion. 1995. "Poverty and Household Size." The Economic Journal 433: 1415-1434. 
Louat, Frederic, Jacques van der Gaag, and Margaret Grosh. 1993. "Welfare Implications of Female Headship in Jamaican Households." LSMS Working Paper No. 96, Poverty and Human Resources Division. World Bank, Washington, D.C.

Marenya Paswel P., Menale B. Kassie, Moti D. Jaleta \& Dil B. Rahut. 2017. "Maize Market Participation among Female- and Male-Headed Households in Ethiopia." The Journal of Development Studies 53(4): 481-494.

Milazzo, Annamaria and Dominique van de Walle. 2017. "Women Left Behind? Poverty and Headship in Africa.” Demography 54(3): 1119-1145.

Milazzo, Annamaria and Dominique van de Walle. 2019. "Nutrition, Religion and Widowhood in Nigeria." Economic Development and Cultural Change, forthcoming.

Munoz-Boudet, Ana Maria, Paola Buitrago, Benedicte De La Briere, David Newhouse, Eliana Rubiano Matulevich, Kinnon Scott, and Pablo Suarez-Becerra. 2018. "Gender Differences in Poverty and Household Composition through the Life-Cycle: A Global Perspective.” Policy Research Working Paper No. 8360. World Bank, Washington, DC. https://openknowledge.worldbank.org/handle/10986/29426 License: CC BY 3.0 IGO.

Ndiritu, S. Wagura, Menale Kassie, and Bekele Shiferaw. 2014. “Are There Systematic Gender Differences in the Adoption of Sustainable Agricultural Intensification Practices? Evidence from Kenya." Food Policy 49: 117-127.

OECD. 2011. Divided We Stand - Why Inequality Keeps Rising, Paris: OECD.

O'Sullivan, Michael, Arathi Rao, Raka Banerjee, Kajal Gulati and Margaux Vinez. 2014. "Levelling the field: improving opportunities for women farmers in Africa." World Bank Working Paper 86039, World Bank, Washington DC.

Oginni, Ayodeji, Babatunde Ahonsi, and Francis Ukwuije. 2013. "Are Female-headed Households Typically Poorer than Male-headed Households in Nigeria?" The Journal of Socio-Economics 45: 132-137.

Oseni, Gbemisola, Paul Corral, Markus Goldstein, and Paul Winters. 2015. "Explaining Gender Differentials in Agricultural Production in Nigeria." Agricultural Economics 46(3): 285-310.

Palacios-Lopez, Amparo, Luc Christiaensen, and Talip Kilic. 2017. "How Much of the Labor in African Agriculture is Provided by Women?” Food Policy 67: 52-63.

Peterman, Amber. 2012. "Widowhood and Asset Inheritance in Sub-Saharan Africa: Empirical Evidence from 15 Countries.” Development Policy Review 30(5): 543-571. 
Peterman, Amber, Julia Behrman, and Agnes Quisumbing. 2010. “A Review of Empirical Evidence on Gender Differences in Non-Land Agricultural Inputs, Technology, and Services in Developing Countries." Discussion Paper Number 00975, International Food Policy Research Institute, Washington, DC.

Peterman, Amber, Agnes Quisumbing, Julia Behrman, and Ephraim Nkonya. 2011. "Understanding the Complexities Surrounding Gender Differences in Agricultural Productivity in Nigeria and Uganda." Journal of Development Studies 47(10): 1482-1508.

Pollak, Robert, and Terence Wales. 1979. "Welfare Comparison and Equivalence Scale." American Economic Review 69: 216-221.

Posel, Dorrit. 2001. "Who are the Heads of Household, What Do They Do, and is the Concept of Headship Useful? An Analysis of Headship in South Africa." Development Southerm Africa 18 (5): 651-670.

Posel, Dorrit and Michael Rogan. 2012. "Gendered Trends in Poverty in the Post-Apartheid Period, 1997-2006.” Development Southern Africa 29(1): 97-113.

Quisumbing, Agnes R. 1996. "Male-Female Differences in Agricultural Productivity: Methodological Issues and Empirical Evidence.” World Development 24(10): 1579-1595.

Quisumbing, Agnes, Lawrence Haddad, and Christine Pena. 2001. "Are Women Overrepresented Among the Poor? An Analysis of Poverty in Ten Developing Countries." Journal of Development Economics 66(1): 225-269.

Ragasa, Catherine, Guush Berhane, Fanaye Tadesse, and Alemayehu Seyoum Taffesse. 2013. "Gender Differences in Access to Extension Services and Agricultural Productivity." The Journal of Agricultural Education and Extension 19(5): 437-468.

Ravallion, Martin. 2015. "On Testing the Scale Sensitivity of Poverty Measures.” Economics Letters 137: 88-90.

Ravallion, Martin, Shaohua Chen, and Prem Sangraula. 2009. "Dollar a Day Revisited." World Bank Economic Review 23(2): 163-184.

Rogan, Michael. 2013. "Poverty and Headship in Post-Apartheid South-Africa, 1997-2008." Social Indicators Research 113(1): 491-511.

Rosenhouse, Sandra. 1989. "Identifying the Poor: Is Headship a Useful Concept?” Living Standards Measurement Study Working Paper No. 58, Washington DC: World Bank.

Slavchevska, Vanya. 2015. "Gender Differences in Agricultural Productivity: The Case of Tanzania.” Agricultural Economics 46(3): 335-355. 
Sossou, Marie-Antoinette. 2002. "Widowhood Practices in West Africa: The Silent Victims.” International Journal of Social Welfare 11(3): 201-209.

Tiruneh, Addis, Teklu Tesfaye, Wilfred Mwangi, and Hugo Verkuijl. 2001. Gender differentials in agricultural production and decision-making among smallholders in Ada, Lume, and Gimbichu Woredas of the Central Highlands of Ethiopia. Mexico, D.F.: International Maize and Wheat Improvement Center (CIMMYT) and Ethiopian Agricultural Research Organization (EARO).

Torkelsson, Åsa. 2007. "Resources, Not Capital: A Case Study of the Gendered Distribution and Productivity of Social Network Ties in Rural Ethiopia." Rural Sociology 72(4): 583607.

Torkelsson, Åsa and Bekele Tassew. 2008. “Quantifying Women's and Men’s Rural Resource Portfolios: Empirical Evidence from Western Shoa in Ethiopia." The European Journal of Development Research 20(3): 462-481.

Udry, Christopher. 1996. "Gender, Agricultural Production, and the Theory of the Household.” Journal of Political Economy 104(5): 1010-1046.

Udry, Christopher, John Hoddinott, Harold Alderman, and Lawrence Haddad. 1995.

"Gender Differentials in Farm Productivity: Implications for Household Efficiency and Agricultural Policy." Food Policy 20(5): 407-423.

van de Walle, Dominique. 2013. "Lasting Welfare Effects of Widowhood in Mali.” World Development 51: 1-19. 
Figure 1. Poverty rates by age and presence of male adult in FHHs compared to all MHHs by region
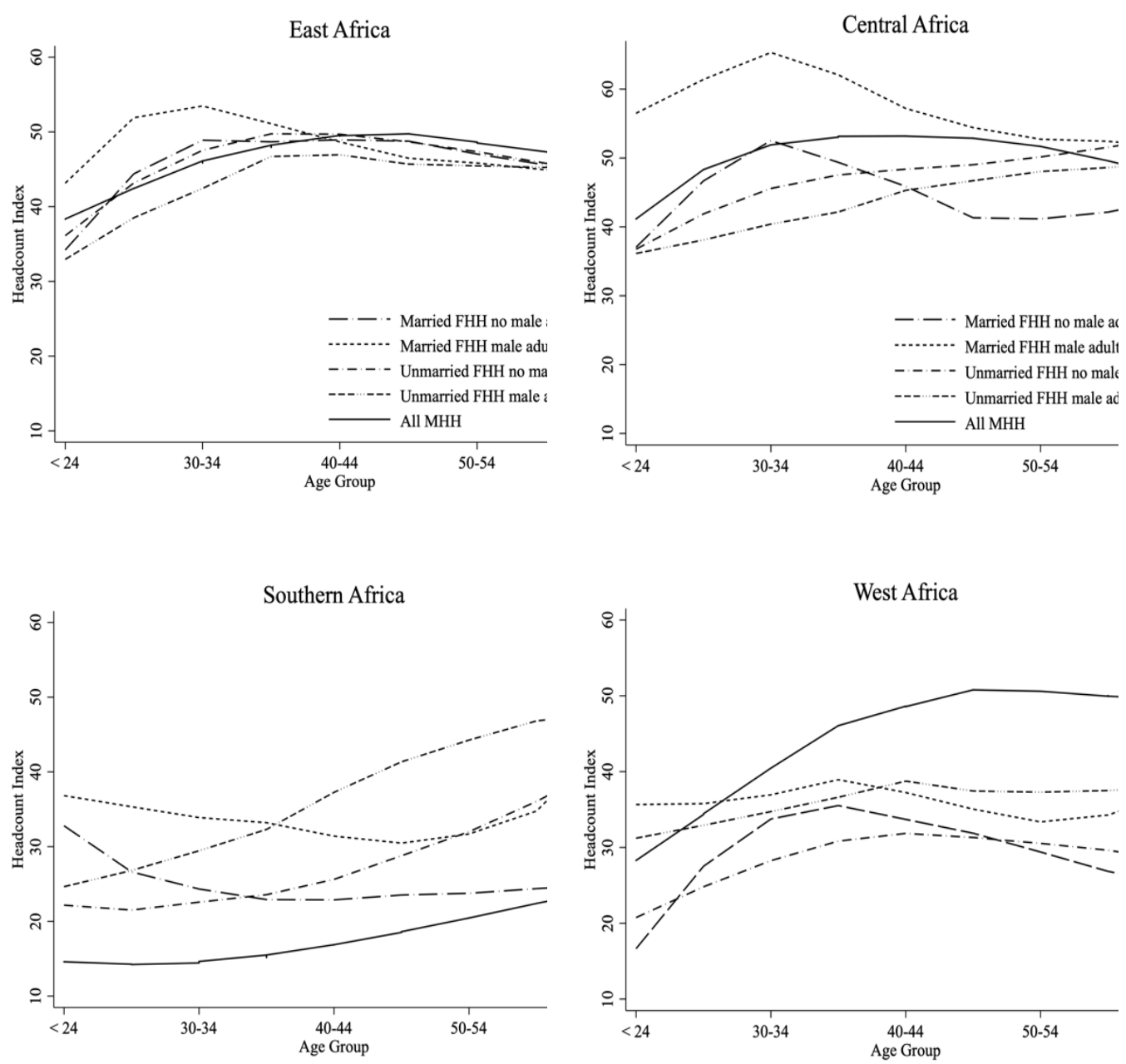

Note: Data are from the PovcalNet harmonized database. MHH and FHH refer to male- and female-headed households, respectively. The figure plots the headcount index by the head's age group for married and unmarried female heads and by whether a male adult resides in the household. Adult is defined as 18 years or older. Unmarried includes divorced, widowed or never married. The solid line delineates the headcount index for all MHHs. Statistics are population weighted. Lowess is used to construct the lines. 
Figure 2. FHH minus MHH differences in poverty rates adjusted for economies of scale by region
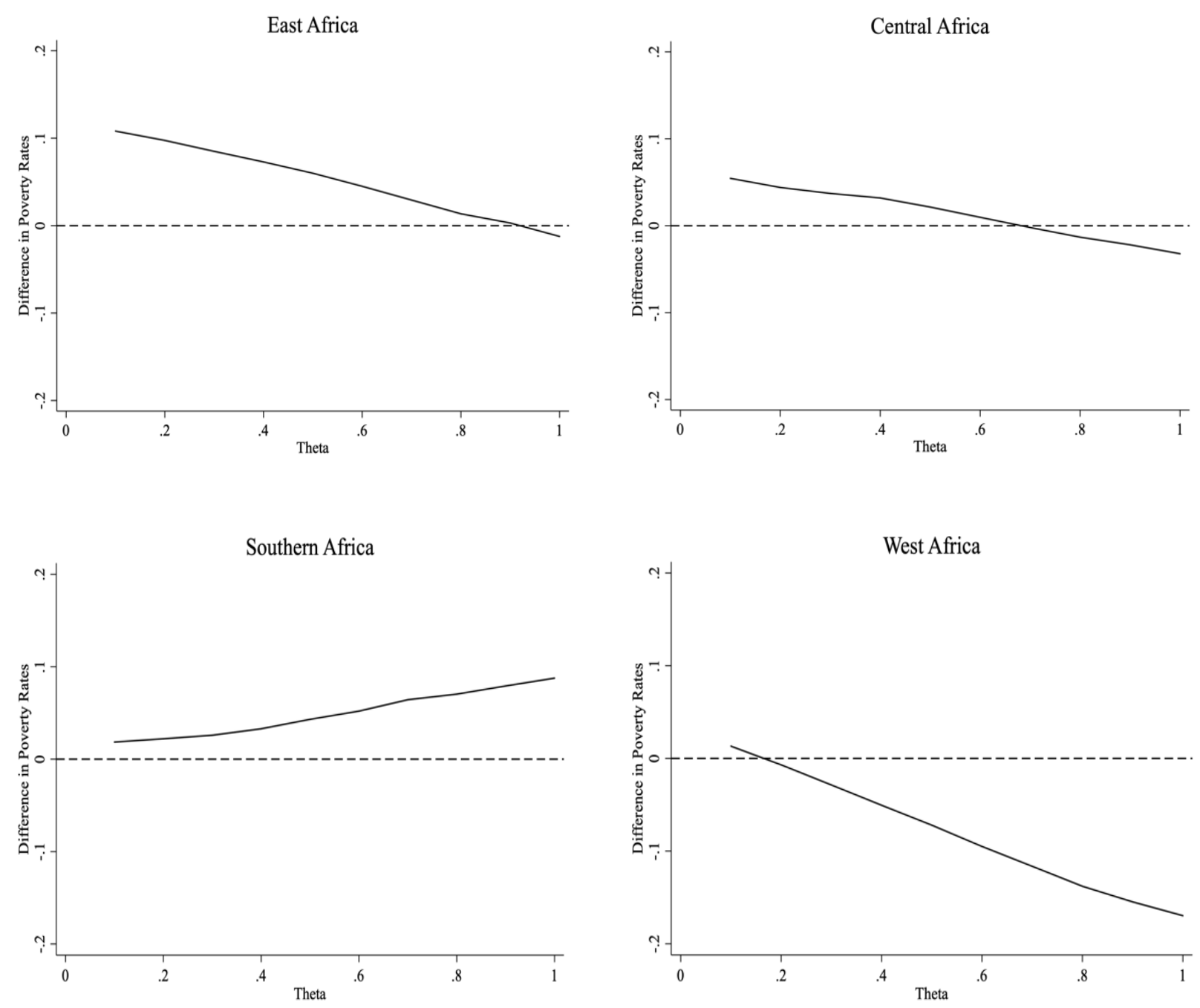

Note: Data are from the PovcalNet harmonized database. The figure plots the difference in the headcount index between FHHs and MHHs adjusted for a complete array of potential economies of scale. A positive difference implies higher poverty for FHHs. Statistics are population weighted. 
Figure 3. Household expenditure CDFs for FHHs and MHHs by region with and without adjustment for scale economies in consumption.

$\underline{\text { Unscaled }}$
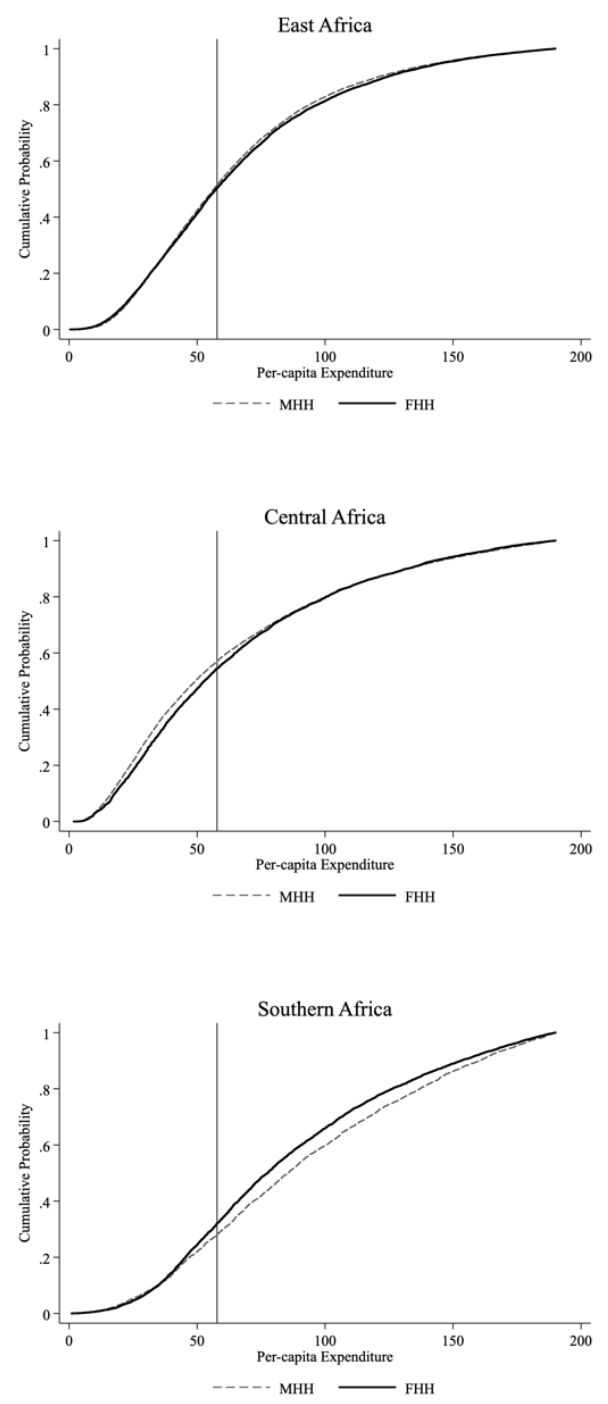

Scaled $(\theta=0.5)$
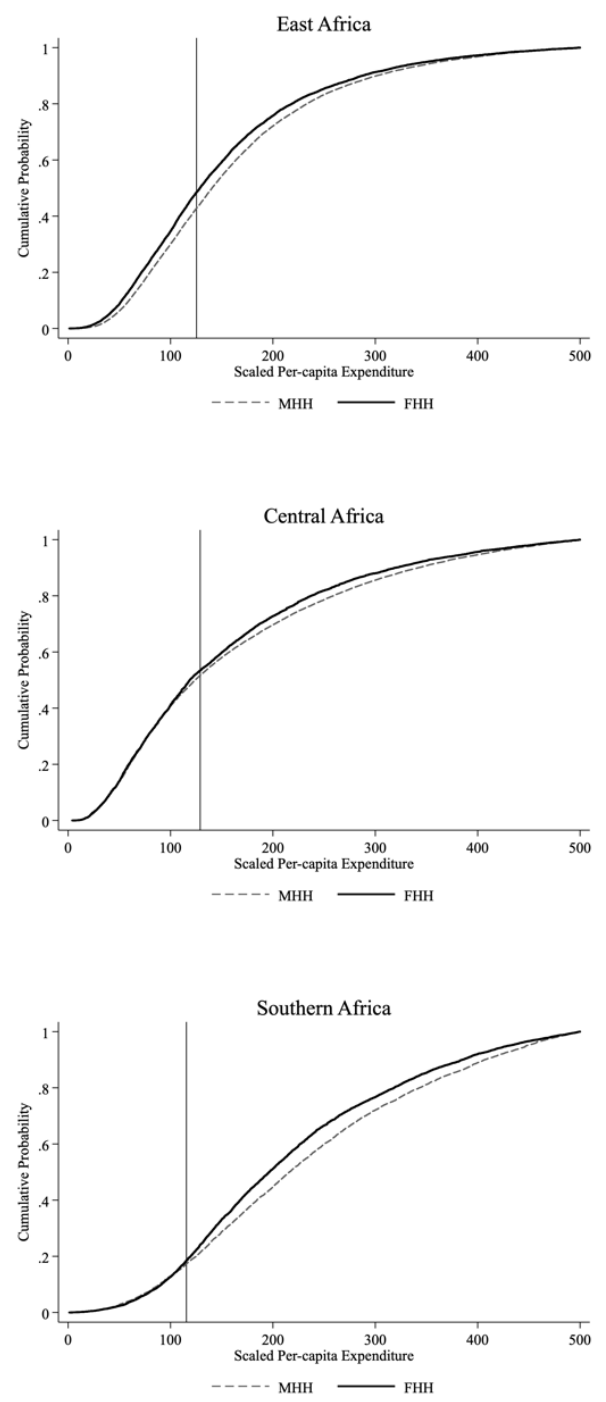

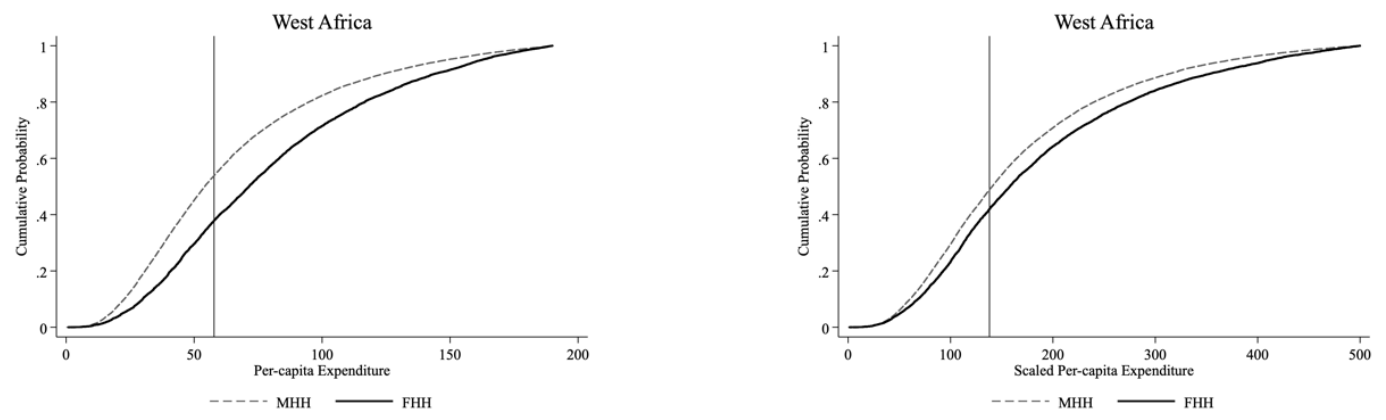

Note: Data are from the PovcalNet harmonized database. The first column shows population weighted CDFs for per capita household expenditure for FHHs and MHHs by region. The vertical line denotes the monthly international per capita poverty line in 2011 PPP (57.73 USD). The second column shows the equivalent figure but accounting for Square root of household size economies of scale. 
Table 1. Prevalence of FHHs by region and sector

\begin{tabular}{|c|c|c|c|c|c|c|}
\hline \multirow[b]{2}{*}{ Region } & \multicolumn{2}{|l|}{ All } & \multicolumn{2}{|l|}{ Rural } & \multicolumn{2}{|l|}{ Urban } \\
\hline & $\begin{array}{l}\text { Share of } \\
\text { households }\end{array}$ & $\begin{array}{l}\text { Share of } \\
\text { population }\end{array}$ & $\begin{array}{l}\text { Share of } \\
\text { households }\end{array}$ & $\begin{array}{l}\text { Share of } \\
\text { population }\end{array}$ & $\begin{array}{l}\text { Share of } \\
\text { households }\end{array}$ & $\begin{array}{l}\text { Share of } \\
\text { population }\end{array}$ \\
\hline \multicolumn{7}{|l|}{ East Africa } \\
\hline Burundi & 0.196 & 0.156 & 0.193 & 0.152 & 0.260 & 0.209 \\
\hline Comoros & 0.218 & 0.174 & 0.214 & 0.169 & 0.228 & 0.187 \\
\hline Ethiopia & 0.249 & 0.179 & 0.217 & 0.153 & 0.368 & 0.309 \\
\hline Kenya & 0.289 & 0.263 & 0.309 & 0.274 & 0.231 & 0.223 \\
\hline Madagascar & 0.193 & 0.149 & 0.184 & 0.140 & 0.224 & 0.183 \\
\hline Malawi & 0.240 & 0.198 & 0.252 & 0.207 & 0.177 & 0.151 \\
\hline Mauritius & 0.212 & 0.167 & - & - & - & - \\
\hline Mozambique & 0.295 & 0.242 & 0.287 & 0.226 & 0.313 & 0.279 \\
\hline Rwanda & 0.277 & 0.225 & 0.280 & 0.225 & 0.257 & 0.223 \\
\hline Seychelles & 0.565 & 0.581 & 0.565 & 0.582 & 0.566 & 0.579 \\
\hline Tanzania & 0.247 & 0.197 & 0.243 & 0.187 & 0.256 & 0.224 \\
\hline Uganda & 0.310 & 0.271 & 0.299 & 0.258 & 0.338 & 0.316 \\
\hline Zambia & 0.235 & 0.198 & 0.238 & 0.194 & 0.230 & 0.205 \\
\hline Total & 0.259 & 0.209 & 0.249 & 0.198 & 0.291 & 0.253 \\
\hline \multicolumn{7}{|l|}{ Central Africa } \\
\hline Angola & 0.233 & 0.184 & 0.231 & 0.172 & 0.235 & 0.194 \\
\hline Cameroon & 0.256 & 0.209 & 0.258 & 0.196 & 0.254 & 0.235 \\
\hline Central Afr. Rep. & 0.218 & 0.188 & 0.184 & 0.145 & 0.286 & 0.260 \\
\hline Chad & 0.208 & 0.156 & 0.201 & 0.146 & 0.239 & 0.204 \\
\hline Congo, Dem. Rep. & 0.197 & 0.157 & 0.188 & 0.137 & 0.215 & 0.190 \\
\hline Congo, Rep. & 0.254 & 0.215 & 0.253 & 0.191 & 0.255 & 0.227 \\
\hline Gabon & 0.266 & 0.267 & 0.252 & 0.227 & 0.270 & 0.277 \\
\hline Sao Tome \& Pri. & 0.382 & 0.366 & 0.336 & 0.335 & 0.428 & 0.395 \\
\hline Sudan & 0.106 & 0.081 & 0.111 & 0.083 & 0.097 & 0.077 \\
\hline Total & 0.199 & 0.155 & 0.191 & 0.138 & 0.212 & 0.182 \\
\hline \multicolumn{7}{|l|}{ Southern Africa } \\
\hline Botswana & 0.456 & 0.501 & 0.462 & 0.512 & 0.452 & 0.493 \\
\hline Lesotho & 0.371 & 0.345 & 0.359 & 0.336 & 0.409 & 0.383 \\
\hline Namibia & 0.573 & 0.559 & 0.549 & 0.534 & 0.605 & 0.599 \\
\hline South Africa & 0.393 & 0.429 & 0.496 & 0.536 & 0.343 & 0.361 \\
\hline Swaziland & 0.464 & 0.495 & 0.516 & 0.532 & 0.375 & 0.379 \\
\hline Total & 0.401 & 0.434 & 0.489 & 0.522 & 0.353 & 0.372 \\
\hline \multicolumn{7}{|l|}{ West Africa } \\
\hline Benin & 0.232 & 0.170 & 0.219 & 0.150 & 0.247 & 0.198 \\
\hline Burkina Faso & 0.133 & 0.082 & 0.121 & 0.068 & 0.162 & 0.134 \\
\hline Cabo Verde & 0.455 & 0.455 & 0.506 & 0.495 & 0.421 & 0.424 \\
\hline Cote d'Ivoire & 0.184 & 0.146 & 0.150 & 0.099 & 0.228 & 0.200 \\
\hline Gambia, The & 0.148 & 0.122 & 0.086 & 0.063 & 0.207 & 0.203 \\
\hline Ghana & 0.295 & 0.233 & 0.270 & 0.199 & 0.328 & 0.288 \\
\hline Guinea & 0.132 & 0.105 & 0.111 & 0.079 & 0.177 & 0.158 \\
\hline Guinea-Bissau & 0.231 & 0.195 & 0.180 & 0.149 & 0.297 & 0.266 \\
\hline Liberia & 0.269 & 0.257 & 0.256 & 0.238 & 0.299 & 0.300 \\
\hline Mali & 0.105 & 0.063 & 0.097 & 0.051 & 0.130 & 0.108 \\
\hline Mauritania & 0.302 & 0.265 & 0.330 & 0.273 & 0.273 & 0.257 \\
\hline Niger & 0.109 & 0.074 & 0.097 & 0.060 & 0.161 & 0.139 \\
\hline Nigeria & 0.158 & 0.102 & 0.138 & 0.086 & 0.190 & 0.132 \\
\hline Senegal & 0.274 & 0.243 & 0.183 & 0.155 & 0.368 & 0.359 \\
\hline Sierra Leone & 0.266 & 0.259 & 0.252 & 0.235 & 0.287 & 0.297 \\
\hline Togo & 0.218 & 0.170 & 0.211 & 0.150 & 0.227 & 0.202 \\
\hline Total & 0.177 & 0.127 & 0.154 & 0.101 & 0.215 & 0.175 \\
\hline Africa & 0.230 & 0.183 & 0.216 & 0.166 & 0.255 & 0.219 \\
\hline
\end{tabular}

Note: Data are from the PovcalNet harmonized database. The table shows shares of all households that are female headed, and shares of the population living in FHHs by country nationally, and by rural and urban locations. Rural/urban is missing for Mauritius. Statistics for Share of households statistics are weighted by household size; share of population by population. 
Table 2. Share of female heads among all heads in different marital status categories

\begin{tabular}{|c|c|c|c|c|c|c|}
\hline Region & $\begin{array}{l}\text { Never } \\
\text { married }\end{array}$ & $\begin{array}{l}\text { Married, } \\
\text { monogamous }\end{array}$ & $\begin{array}{l}\text { Married, } \\
\text { polygamous }\end{array}$ & $\begin{array}{l}\text { Living } \\
\text { together }\end{array}$ & $\begin{array}{l}\text { Divorced or } \\
\text { separated }\end{array}$ & Widowed \\
\hline \multicolumn{7}{|l|}{ East Africa } \\
\hline Burundi & 0.396 & 0.027 & 0.048 & - & 0.656 & 0.842 \\
\hline Comoros & 0.493 & 0.081 & 0.029 & - & 0.836 & 0.927 \\
\hline Ethiopia & 0.312 & 0.085 & - & 0.245 & 0.808 & 0.880 \\
\hline Kenya & 0.116 & 0.251 & 0.111 & 0.631 & 0.742 & 0.895 \\
\hline Madagascar & 0.581 & 0.017 & 0.075 & - & 0.789 & 0.808 \\
\hline Malawi & 0.263 & 0.036 & 0.094 & - & 0.829 & 0.887 \\
\hline Mauritius & 0.384 & 0.028 & - & - & 0.633 & 0.858 \\
\hline Mozambique & 0.414 & 0.094 & 0.333 & 0.063 & 0.812 & 0.880 \\
\hline Rwanda & 0.435 & 0.006 & 0.135 & 0.030 & 0.847 & 0.930 \\
\hline Seychelles & 0.727 & 0.383 & - & 0.487 & 0.699 & 0.854 \\
\hline Tanzania & 0.371 & 0.036 & 0.243 & 0.134 & 0.680 & 0.867 \\
\hline Uganda & 0.278 & 0.078 & 0.444 & 0.668 & - & 0.904 \\
\hline Zambia & 0.400 & 0.038 & 0.585 & 0.806 & 0.718 & 0.893 \\
\hline Total & 0.208 & 0.064 & 0.320 & 0.337 & 0.775 & 0.882 \\
\hline \multicolumn{7}{|l|}{ Central Africa } \\
\hline Angola & 0.647 & 0.023 & - & 0.025 & 0.838 & 0.870 \\
\hline Cameroon & 0.316 & 0.066 & 0.226 & 0.036 & 0.577 & 0.880 \\
\hline Central Afr. Rep. & 0.273 & 0.041 & 0.158 & 0.107 & 0.632 & 0.816 \\
\hline Chad & 0.112 & 0.106 & - & 0.210 & 0.719 & 0.880 \\
\hline Congo, Dem. Rep. & 0.313 & 0.032 & 0.189 & 0.100 & 0.712 & 0.829 \\
\hline Congo, Rep. & 0.380 & 0.020 & 0.238 & 0.043 & 0.707 & 0.879 \\
\hline Gabon & 0.459 & 0.040 & 0.106 & 0.097 & 0.710 & 0.850 \\
\hline Sao Tome \& Pri. & 0.648 & 0.203 & - & 0.146 & 0.788 & 0.788 \\
\hline Sudan & 0.087 & 0.050 & - & - & 0.828 & 0.827 \\
\hline Total & 0.338 & 0.045 & 0.186 & 0.057 & 0.721 & 0.844 \\
\hline \multicolumn{7}{|l|}{ Southern Africa } \\
\hline Botswana & 0.197 & 0.322 & - & 0.607 & 0.826 & 0.572 \\
\hline Lesotho & 0.472 & 0.093 & 0.105 & 0.396 & 0.402 & 0.816 \\
\hline Namibia & - & 0.810 & - & 0.757 & 0.411 & 0.097 \\
\hline Swaziland & 0.547 & 0.294 & - & 0.247 & 0.576 & 0.894 \\
\hline Total & 0.311 & 0.371 & 0.105 & 0.637 & 0.539 & 0.617 \\
\hline \multicolumn{7}{|l|}{ West Africa } \\
\hline Benin & 0.166 & 0.710 & 0.016 & - & 0.584 & 0.848 \\
\hline Burkina Faso & 0.174 & 0.043 & 0.083 & - & 0.482 & 0.876 \\
\hline Cape Verde & 0.724 & 0.219 & - & 0.206 & 0.765 & 0.892 \\
\hline Cote d'Ivoire & 0.223 & 0.070 & - & - & 0.564 & 0.792 \\
\hline Gambia, The & 0.098 & 0.100 & - & - & 0.667 & 0.855 \\
\hline Ghana & 0.245 & 0.122 & 0.002 & 0.275 & 0.694 & 0.832 \\
\hline Guinea & 0.146 & 0.056 & 0.076 & 0.285 & 0.622 & 0.874 \\
\hline Guinea-Bissau & 0.433 & 0.092 & 0.081 & - & 0.553 & 0.879 \\
\hline Liberia & 0.470 & 0.125 & 0.246 & 0.144 & 0.581 & 0.836 \\
\hline Mauritania & 0.202 & 0.166 & 0.131 & - & 0.842 & 0.924 \\
\hline Niger & 0.183 & 0.024 & 0.027 & - & 0.635 & 0.947 \\
\hline Nigeria & - & 0.050 & 0.214 & 0.416 & 0.548 & 0.836 \\
\hline Senegal & 0.179 & 0.130 & 0.250 & - & 0.777 & 0.878 \\
\hline Sierra Leone & 0.309 & 0.149 & 0.163 & 0.428 & 0.638 & 0.901 \\
\hline Togo & 0.183 & 0.071 & 0.199 & - & 0.560 & 0.843 \\
\hline Total & 0.238 & 0.062 & 0.094 & 0.273 & 0.601 & 0.844 \\
\hline Africa & 0.241 & 0.061 & 0.186 & 0.185 & 0.699 & 0.855 \\
\hline $\begin{array}{l}\text { Share of } \\
\text { households }\end{array}$ & 0.074 & 0.637 & 0.067 & 0.051 & 0.056 & 0.15 \\
\hline
\end{tabular}

Note: Data are from the PovcalNet harmonized database. The table shows proportions of households with a female head among all households classified by their head's marital status. For example, 39.6\% of all never married heads in Burundi are female. Marital status is missing for Mali and South Africa. Blank cells indicate that the category was missing for the country in the database. Statistics are household weighted. 
Table 3. Household descriptive statistics by sector and gender of head

\begin{tabular}{|c|c|c|c|c|c|c|c|c|}
\hline & \multicolumn{4}{|c|}{ Rural } & \multicolumn{4}{|c|}{ Urban } \\
\hline & & & \multicolumn{2}{|c|}{ FHH } & & & \multicolumn{2}{|c|}{ FHH } \\
\hline & МHH & FHH & $\begin{array}{c}\text { No } \\
\text { adult } \\
\text { male }\end{array}$ & $\begin{array}{l}\text { Adult } \\
\text { male }\end{array}$ & MHH & FHH & $\begin{array}{c}\text { No } \\
\text { adult } \\
\text { male }\end{array}$ & $\begin{array}{c}\text { Adult } \\
\text { male }\end{array}$ \\
\hline $\begin{array}{l}\text { Share of } \\
\text { households }\end{array}$ & 0.784 & 0.216 & 0.685 & 0.315 & 0.745 & 0.255 & 0.643 & 0.357 \\
\hline \multicolumn{9}{|l|}{ Head characteristics } \\
\hline Age & 44.40 & 49.29 & 48.33 & 51.38 & 43.20 & 46.43 & 44.26 & 50.36 \\
\hline No education & 0.407 & 0.559 & 0.564 & 0.548 & 0.141 & 0.281 & 0.276 & 0.291 \\
\hline At least primary & 0.385 & 0.251 & 0.249 & 0.256 & 0.739 & 0.557 & 0.575 & 0.525 \\
\hline At least secondary & 0.172 & 0.068 & 0.073 & 0.059 & 0.410 & 0.231 & 0.251 & 0.195 \\
\hline Never married & 0.060 & 0.061 & 0.064 & 0.054 & 0.094 & 0.118 & 0.145 & 0.065 \\
\hline $\begin{array}{l}\text { Married, } \\
\text { monogamous }\end{array}$ & 0.774 & 0.179 & 0.172 & 0.195 & 0.739 & 0.184 & 0.184 & 0.186 \\
\hline $\begin{array}{l}\text { Married, } \\
\text { polygamous }\end{array}$ & 0.079 & 0.068 & 0.059 & 0.089 & 0.049 & 0.040 & 0.031 & 0.057 \\
\hline Living together & 0.046 & 0.042 & 0.041 & 0.043 & 0.07 & 0.048 & 0.051 & 0.041 \\
\hline $\begin{array}{l}\text { Divorced or } \\
\text { separated }\end{array}$ & 0.019 & 0.169 & 0.192 & 0.114 & 0.028 & 0.204 & 0.220 & 0.172 \\
\hline Widowed & 0.021 & 0.482 & 0.472 & 0.505 & 0.021 & 0.406 & 0.370 & 0.479 \\
\hline \multicolumn{9}{|l|}{$\begin{array}{l}\text { Household } \\
\text { demographics }\end{array}$} \\
\hline Household size & 5.384 & 3.901 & 3.219 & 5.383 & 4.571 & 3.771 & 2.852 & 5.426 \\
\hline Dependency ratio & 1.058 & 1.225 & 1.456 & 0.790 & 0.720 & 0.811 & 0.963 & 0.563 \\
\hline One adult & 0.071 & 0.181 & 0.264 & 0.002 & 0.137 & 0.213 & 0.330 & 0.003 \\
\hline $\begin{array}{l}\text { One adult + } \\
\text { children }\end{array}$ & 0.018 & 0.338 & 0.492 & 0.005 & 0.013 & 0.232 & 0.357 & 0.005 \\
\hline $\begin{array}{l}\text { Two adults }+ \\
\text { children }\end{array}$ & 0.482 & 0.187 & 0.136 & 0.298 & 0.385 & 0.158 & 0.140 & 0.191 \\
\hline $\mathrm{N}$ & 174,405 & 56,468 & 36,328 & 20,140 & 135,437 & 54,242 & 33,476 & 20,766 \\
\hline
\end{tabular}

Note: Data are from the PovcalNet harmonized database. The table shows averages over all countries for key household attributes by gender of the head. The last two columns of each sector group divide FHHs into whether an adult male resides in the household or not. No education indicates never attended school. Dependency ratio is defined as the number of members aged 0 to 14 and 65 and older divided by the number aged 15 to 64 years. One adult indicates that the household is composed solely of the head. Adults are defined as 18 years or older. Children are members 14 years and younger. Statistics are household weighted. 
Table 4. Household demographic composition by sector and gender of head (LSMS surveys)

\begin{tabular}{|c|c|c|c|c|c|c|c|c|}
\hline & \multicolumn{4}{|c|}{ Rural } & \multicolumn{4}{|c|}{ Urban } \\
\hline & \multicolumn{4}{|c|}{ FHH } & \multirow[b]{2}{*}{ МHH } & \multirow[b]{2}{*}{ FHH } & \multicolumn{2}{|c|}{ FHH } \\
\hline & МHH & FHH & $\begin{array}{c}\text { No } \\
\text { adult } \\
\text { male }\end{array}$ & $\begin{array}{c}\text { Adult } \\
\text { male }\end{array}$ & & & $\begin{array}{c}\text { No } \\
\text { adult } \\
\text { male }\end{array}$ & $\begin{array}{c}\text { Adult } \\
\text { male }\end{array}$ \\
\hline Total share of households & 0.80 & 0.20 & 0.55 & 0.45 & 0.74 & 0.26 & 0.61 & 0.39 \\
\hline \multicolumn{9}{|l|}{ Head characteristics } \\
\hline Age & 47.16 & 53.00 & 53.02 & 52.96 & 46.17 & 49.88 & 48.40 & 52.21 \\
\hline At least primary education & 0.34 & 0.16 & 0.17 & 0.14 & 0.74 & 0.48 & 0.50 & 0.46 \\
\hline At least secondary education & 0.16 & 0.05 & 0.06 & 0.05 & 0.45 & 0.23 & 0.23 & 0.24 \\
\hline \multicolumn{9}{|l|}{ Marital status } \\
\hline Married & 0.91 & 0.19 & 0.17 & 0.22 & 0.81 & 0.18 & 0.16 & 0.21 \\
\hline Living together & 0.04 & 0.03 & 0.03 & 0.02 & 0.04 & 0.02 & 0.02 & 0.02 \\
\hline Divorced/separated & 0.02 & 0.19 & 0.22 & 0.15 & 0.03 & 0.23 & 0.24 & 0.20 \\
\hline Widowed & 0.02 & 0.57 & 0.55 & 0.61 & 0.03 & 0.44 & 0.39 & 0.52 \\
\hline Never married & 0.02 & 0.04 & 0.05 & 0.02 & 0.09 & 0.14 & 0.19 & 0.05 \\
\hline \multicolumn{9}{|c|}{ Housebold demographics } \\
\hline Household size & 6.14 & 3.88 & 2.96 & 5.03 & 5.04 & 3.47 & 2.53 & 4.91 \\
\hline Dependency ratio & 1.17 & 1.15 & 1.50 & 0.83 & 0.80 & 0.75 & 0.86 & 0.60 \\
\hline Share 0 to 14 years: & 0.42 & 0.34 & 0.36 & 0.30 & 0.32 & 0.25 & 0.27 & 0.23 \\
\hline Share 15 to 64 years: Female & 0.25 & 0.35 & 0.40 & 0.30 & 0.25 & 0.48 & 0.56 & 0.36 \\
\hline Male & 0.27 & 0.14 & - & 0.32 & 0.36 & 0.13 & - & 0.33 \\
\hline Share 65 yrs \& older: Female & 0.02 & 0.14 & 0.21 & 0.06 & 0.01 & 0.12 & 0.16 & 0.05 \\
\hline Male & 0.04 & 0.00 & - & 0.01 & 0.04 & 0.00 & - & 0.00 \\
\hline \multicolumn{9}{|l|}{ Members include at least one: } \\
\hline \multirow{3}{*}{$\begin{array}{l}\text { Working male: Age } 18 \text { to } 64 \\
\text { Age } 13 \text { to } 17 \\
\text { Widow }\end{array}$} & 0.78 & 0.23 & - & 0.50 & 0.75 & 0.14 & - & 0.36 \\
\hline & 0.14 & 0.14 & 0.04 & 0.25 & 0.03 & 0.02 & 0.01 & 0.04 \\
\hline & 0.09 & 0.57 & 0.53 & 0.61 & 0.11 & 0.43 & 0.36 & 0.53 \\
\hline Disabled adult: Female 15-64 & 0.03 & 0.05 & 0.06 & 0.04 & 0.03 & 0.02 & 0.00 & 0.05 \\
\hline Male 15-64 & 0.03 & 0.02 & - & 0.03 & 0.03 & 0.02 & - & 0.05 \\
\hline Female $65+$ & 0.01 & 0.08 & 0.10 & 0.04 & 0.01 & 0.08 & 0.11 & 0.04 \\
\hline Male $65+$ & 0.03 & 0.00 & - & 0.01 & 0.02 & 0.00 & - & 0.01 \\
\hline Orphan & 0.02 & 0.03 & 0.02 & 0.03 & 0.01 & 0.02 & 0.02 & 0.03 \\
\hline \multicolumn{9}{|l|}{ Relatives of head in b'bold } \\
\hline Spouse & 0.93 & 0.06 & 0.00 & 0.12 & 0.82 & 0.05 & 0.00 & 0.11 \\
\hline Daughter & 0.71 & 0.46 & 0.41 & 0.53 & 0.60 & 0.44 & 0.37 & 0.55 \\
\hline Son & 0.76 & 0.50 & 0.28 & 0.77 & 0.63 & 0.40 & 0.18 & 0.76 \\
\hline Mother & 0.06 & 0.02 & 0.02 & 0.02 & 0.03 & 0.02 & 0.01 & 0.02 \\
\hline Father & 0.01 & 0.00 & 0.00 & 0.00 & 0.00 & 0.00 & 0.00 & 0.00 \\
\hline Sister & 0.02 & 0.02 & 0.02 & 0.01 & 0.03 & 0.04 & 0.00 & 0.06 \\
\hline Brother & 0.03 & 0.02 & 0.00 & 0.04 & 0.04 & 0.03 & 0.05 & 0.04 \\
\hline Son/daughter-in-law & 0.02 & 0.03 & 0.01 & 0.06 & 0.02 & 0.01 & 0.00 & 0.02 \\
\hline $\mathrm{N}$ & 23,268 & 5,407 & 3,142 & 2,265 & 11,730 & 3,590 & 2,014 & 1,576 \\
\hline
\end{tabular}


Note: Data are from the LSMS surveys. Average values of household and head characteristics by type are shown. The last two columns divide FHHs into whether an adult male (18 years of age or older) resides in the household. The living together category is only available for Burkina Faso, Ghana, and Tanzania. Dependency ratio is the number of household members aged 0 to 14 and 65 and older divided by the number aged 15 to 64 years.

Demographic shares refer to the number of members in each category divided by household size. Working male refers to at least one male within the specified age ranges who worked at some point in the past 12 months.

Disabled adult indicates at least one disabled household member in each age range. Orphans are aged 15 years or younger with both parents deceased/unknown/missing. Household members with missing values for age or who have been absent for more than 11 months are excluded. Statistics are household weighted. 
Table 5. Access to remittances by head's gender and marital status

\begin{tabular}{|c|c|c|c|}
\hline $\begin{array}{l}\text { All households (married male heads } \\
\text { is omitted category) }\end{array}$ & All & Rural & Urban \\
\hline Not married male head & $\begin{array}{l}0.02 * \\
(1.87)\end{array}$ & $\begin{array}{c}0.01 \\
(0.58)\end{array}$ & $\begin{array}{l}0.02 \\
(1.60)\end{array}$ \\
\hline Not married female head & $\begin{array}{l}0.12^{* * *} \\
(15.08)\end{array}$ & $\begin{array}{l}0.12^{* * *} \\
(12.53)\end{array}$ & $\begin{array}{c}0.12^{* * *} \\
(7.93)\end{array}$ \\
\hline Married female head & $\begin{array}{c}0.19 * * * \\
(9.87)\end{array}$ & $\begin{array}{c}0.19^{* * *} \\
(8.51)\end{array}$ & $\begin{array}{r}0.17^{* * *} \\
(4.98)\end{array}$ \\
\hline $\mathrm{N}$ & 38842 & 25582 & 13260 \\
\hline $\begin{array}{l}\text { Female-headed households (not } \\
\text { married, no male omitted) }\end{array}$ & All & Rural & Urban \\
\hline Not married, male adult & $\begin{array}{c}-0.04 * * * \\
(-2.64)\end{array}$ & $\begin{array}{l}-0.02 \\
(-1.23)\end{array}$ & $\begin{array}{c}-0.06^{* *} \\
(-2.17)\end{array}$ \\
\hline Married, male adult & $\begin{array}{c}-0.07^{* * *} \\
(-2.79)\end{array}$ & $\begin{array}{l}-0.05 \\
(-1.46)\end{array}$ & $\begin{array}{l}-0.11^{* * *} \\
(-2.97)\end{array}$ \\
\hline Married, no male adult & $\begin{array}{c}0.10^{* * *} \\
(3.26)\end{array}$ & $\begin{array}{c}0.09^{* * *} \\
(2.63)\end{array}$ & $\begin{array}{l}0.12^{* *} \\
(2.20)\end{array}$ \\
\hline $\mathrm{N}$ & 7359 & 4553 & 2806 \\
\hline
\end{tabular}

Note: Data are from the LSMS surveys. The table shows regression coefficients for whether or not the household receives remittances. Urban is controlled for in the All column, and regressions include country fixed effects. Male adult is defined as any male over 18 years of age residing in the household. The base for All households is married male-headed households. The base for FHH is not married with no male adult. Not married includes all other marital status categories of the head. Robust standard errors and population weights are used. t-statistics in parentheses. * prob. $<.10 * *$ prob. $<.05 * * *$ prob. $<.01$ 
Table 6. Household poverty measures by gender of head and FHH minus MHH differences

\begin{tabular}{|c|c|c|c|c|c|c|c|c|c|}
\hline \multirow[b]{2}{*}{ Region } & \multicolumn{3}{|c|}{ Headcount Index } & \multicolumn{3}{|c|}{ Poverty Gap Index } & \multicolumn{3}{|c|}{ Squared Poverty Gap Index } \\
\hline & FHH & MHH & Diff & FHH & МHH & Diff & FHH & МHH & Diff \\
\hline \multicolumn{10}{|l|}{ East Africa } \\
\hline Burundi & 0.769 & 0.778 & -0.009 & 0.310 & 0.332 & $-0.023^{* *}$ & 0.152 & 0.167 & $-0.015^{* *}$ \\
\hline Comoros & 0.138 & 0.134 & 0.004 & 0.041 & 0.036 & 0.005 & 0.018 & 0.014 & 0.004 \\
\hline Ethiopia & 0.294 & 0.344 & $-0.050^{* * *}$ & 0.078 & 0.093 & $-0.016^{* * *}$ & 0.031 & 0.038 & $-0.007 * *$ \\
\hline Kenya & 0.357 & 0.329 & $0.028^{* *}$ & 0.133 & 0.111 & $0.022^{* * *}$ & 0.070 & 0.053 & $0.017^{* * *}$ \\
\hline Madagascar & 0.815 & 0.818 & -0.003 & 0.419 & 0.400 & $0.019 * *$ & 0.254 & 0.233 & $0.021^{* * *}$ \\
\hline Malawi & 0.757 & 0.697 & $0.060^{* * *}$ & 0.375 & 0.323 & $0.052^{* * *}$ & 0.220 & 0.183 & $0.037^{* * *}$ \\
\hline Mauritius & 0.012 & 0.004 & $0.009 * *$ & 0.003 & 0.001 & $0.002 * *$ & 0.001 & 0.000 & $0.001 * *$ \\
\hline Mozambique & 0.686 & 0.692 & -0.006 & 0.317 & 0.316 & 0.000 & 0.184 & 0.181 & 0.002 \\
\hline Rwanda & 0.609 & 0.603 & 0.006 & 0.243 & 0.237 & 0.006 & 0.124 & 0.119 & 0.005 \\
\hline Seychelles & 0.006 & 0.000 & 0.006 & 0.001 & 0.000 & 0.001 & 0.000 & 0.000 & 0.000 \\
\hline Tanzania & 0.511 & 0.485 & 0.026 & 0.154 & 0.154 & -0.000 & 0.064 & 0.065 & -0.002 \\
\hline Uganda & 0.353 & 0.325 & 0.027 & 0.113 & 0.097 & $0.015^{* *}$ & 0.051 & 0.041 & $0.010^{* * *}$ \\
\hline Zambia & 0.646 & 0.644 & 0.002 & 0.322 & 0.314 & 0.008 & 0.194 & 0.186 & 0.007 \\
\hline Total & 0.466 & 0.478 & $-0.012^{* *}$ & 0.178 & 0.180 & -0.002 & 0.093 & 0.092 & 0.001 \\
\hline \multicolumn{10}{|l|}{ Central Africa } \\
\hline Angola & 0.271 & 0.308 & $-0.037^{*}$ & 0.088 & 0.098 & -0.010 & 0.041 & 0.045 & -0.004 \\
\hline Cameroon & 0.227 & 0.310 & $-0.083^{* * *}$ & 0.058 & 0.090 & $-0.032^{* * *}$ & 0.020 & 0.035 & $-0.015^{* * *}$ \\
\hline Central Afr. Rep. & 0.636 & 0.669 & $-0.033^{*}$ & 0.325 & 0.332 & -0.008 & 0.205 & 0.206 & -0.001 \\
\hline Chad & 0.341 & 0.392 & $-0.051 * *$ & 0.129 & 0.157 & $-0.028^{* *}$ & 0.066 & 0.084 & $-0.018^{* *}$ \\
\hline Congo, Dem. Rep. & 0.713 & 0.783 & $-0.069 * * *$ & 0.344 & 0.401 & $-0.057^{* * *}$ & 0.205 & 0.247 & $-0.042 * * *$ \\
\hline Congo, Rep. & 0.290 & 0.286 & 0.003 & 0.105 & 0.093 & $0.012^{*}$ & 0.051 & 0.042 & $0.009 * *$ \\
\hline Gabon & 0.104 & 0.071 & $0.033 * *$ & 0.027 & 0.015 & $0.011^{* * *}$ & 0.011 & 0.005 & $0.005^{* *}$ \\
\hline Sao Tome \& Pri. & 0.377 & 0.317 & $0.060^{* *}$ & 0.103 & 0.084 & $0.018^{*}$ & 0.039 & 0.032 & 0.008 \\
\hline
\end{tabular}




\begin{tabular}{|c|c|c|c|c|c|c|c|c|c|}
\hline Sudan & 0.168 & 0.148 & 0.020 & 0.043 & 0.039 & 0.004 & 0.018 & 0.016 & 0.001 \\
\hline Total & 0.488 & 0.520 & $-0.032 * * *$ & 0.216 & 0.242 & $-0.027 * * *$ & 0.123 & 0.143 & $-0.019 * * *$ \\
\hline \multicolumn{10}{|c|}{ Southern Africa } \\
\hline Botswana & 0.210 & 0.154 & $0.056^{* * *}$ & 0.069 & 0.047 & $0.022^{* * *}$ & 0.032 & 0.021 & $0.011^{* * *}$ \\
\hline Lesotho & 0.599 & 0.595 & 0.004 & 0.328 & 0.313 & 0.015 & 0.221 & 0.204 & 0.017 \\
\hline Namibia & 0.207 & 0.250 & $-0.043^{* * *}$ & 0.059 & 0.076 & $-0.016^{* * *}$ & 0.025 & 0.032 & $-0.006 * *$ \\
\hline South Africa & 0.223 & 0.122 & $0.101 * * *$ & 0.065 & 0.037 & $0.028 * * *$ & 0.027 & 0.016 & $0.011^{* * *}$ \\
\hline Swaziland & 0.473 & 0.369 & $0.104 * * *$ & 0.194 & 0.139 & $0.055^{* * *}$ & 0.103 & 0.071 & $0.032^{* * *}$ \\
\hline Total & 0.237 & 0.150 & $0.088^{* * *}$ & 0.075 & 0.051 & $0.024 * * *$ & 0.034 & 0.025 & $0.009 * * *$ \\
\hline \multicolumn{10}{|l|}{ West Africa } \\
\hline Benin & 0.390 & 0.560 & $-0.170^{* * *}$ & 0.126 & 0.203 & $-0.077 * * *$ & 0.054 & 0.096 & $-0.042^{* * *}$ \\
\hline Burkina Faso & 0.450 & 0.562 & $-0.113^{* * *}$ & 0.157 & 0.203 & $-0.046^{* * *}$ & 0.073 & 0.096 & $-0.023^{* * *}$ \\
\hline Cabo Verde & 0.105 & 0.060 & $0.045^{* * *}$ & 0.025 & 0.013 & $0.013^{* * *}$ & 0.010 & 0.004 & $0.005^{* * *}$ \\
\hline Cote d'Ivoire & 0.264 & 0.295 & $-0.031 *$ & 0.093 & 0.105 & -0.012 & 0.048 & 0.052 & -0.004 \\
\hline Gambia, The & 0.488 & 0.735 & $-0.247 * * *$ & 0.196 & 0.383 & $-0.187 * * *$ & 0.105 & 0.240 & $-0.135^{* * *}$ \\
\hline Ghana & 0.168 & 0.277 & $-0.109^{* * *}$ & 0.047 & 0.095 & $-0.049 * * *$ & 0.019 & 0.047 & $-0.028^{* * *}$ \\
\hline Guinea & 0.317 & 0.357 & $-0.040^{* *}$ & 0.092 & 0.105 & -0.012 & 0.039 & 0.044 & -0.005 \\
\hline Guinea-Bissau & 0.624 & 0.682 & $-0.058^{* * *}$ & 0.268 & 0.314 & $-0.047 * * *$ & 0.149 & 0.182 & $-0.034 * * *$ \\
\hline Liberia & 0.668 & 0.693 & -0.024 & 0.261 & 0.288 & $-0.027^{*}$ & 0.136 & 0.157 & $-0.021 * *$ \\
\hline Mali & 0.318 & 0.509 & $-0.191 * * *$ & 0.085 & 0.159 & $-0.075^{* * *}$ & 0.035 & 0.067 & $-0.033^{* * *}$ \\
\hline Mauritania & 0.050 & 0.067 & $-0.017^{* *}$ & 0.013 & 0.017 & -0.004 & 0.006 & 0.006 & -0.001 \\
\hline Niger & 0.427 & 0.509 & $-0.082 * *$ & 0.107 & 0.142 & $-0.035^{* * *}$ & 0.041 & 0.054 & $-0.013^{* *}$ \\
\hline Nigeria & 0.370 & 0.554 & $-0.184 * * *$ & 0.130 & 0.228 & $-0.098^{* * *}$ & 0.064 & 0.122 & $-0.057 * * *$ \\
\hline Senegal & 0.222 & 0.430 & $-0.208^{* * *}$ & 0.061 & 0.149 & $-0.089 * * *$ & 0.024 & 0.071 & $-0.047^{* * *}$ \\
\hline Sierra Leone & 0.493 & 0.534 & $-0.040^{* *}$ & 0.151 & 0.173 & $-0.022^{* * *}$ & 0.062 & 0.075 & $-0.013^{* * *}$ \\
\hline Togo & 0.481 & 0.554 & $-0.074 * * *$ & 0.203 & 0.238 & $-0.035^{* * *}$ & 0.111 & 0.130 & $-0.019 * *$ \\
\hline Total & 0.332 & 0.502 & $-0.170 * * *$ & 0.111 & 0.193 & $-0.081 * * *$ & 0.053 & 0.099 & $-0.046 * * *$ \\
\hline Africa & 0.396 & 0.480 & $-0.085^{* * *}$ & 0.150 & 0.192 & $-0.042 * * *$ & 0.078 & 0.102 & $-0.024 * * *$ \\
\hline
\end{tabular}


Note: Data are from the PovcalNet harmonized database. Per capita household monthly expenditures in 2011 PPP are used. The poverty line is set at $\$ 1.90$ per day. Diff is the difference in means between MHHs and FHHs. A positive value implies that FHHs have a higher average value; e.g. they are poorer per the poverty index. Statistics are population weighted. $\mathrm{N}=315,099$ for $\mathrm{MHH}$ and $\mathrm{N}=112,153$ for FHH. $*$ prob. $<.10 * *$ prob. $<.05 * * *$ prob. $<.01$ 
Table 7. Differences in the poverty rate by sector and head's marital status

\begin{tabular}{|c|c|c|c|c|c|}
\hline & $\begin{array}{c}\text { East } \\
\text { Africa }\end{array}$ & $\begin{array}{c}\text { Central } \\
\text { Africa }\end{array}$ & $\begin{array}{c}\text { Southern } \\
\text { Africa }\end{array}$ & $\begin{array}{c}\text { West } \\
\text { Africa }\end{array}$ & All \\
\hline \multicolumn{6}{|c|}{ Difference: FHH minus MHH by marital status of head } \\
\hline Rural: Never married & $0.065^{* * *}$ & $0.200 * * *$ & $0.079 *$ & 0.013 & $0.066^{* * *}$ \\
\hline Married & -0.020 & $-0.041 * *$ & $-0.162 * * *$ & $-0.156^{* * *}$ & $-0.077 * * *$ \\
\hline Divorced/widowed & $0.058^{* *}$ & $0.095^{* * *}$ & $0.136^{* * *}$ & -0.008 & $0.062 * * *$ \\
\hline All & -0.003 & $-0.020 * *$ & $0.050 * * *$ & $-0.174 * * *$ & $-0.079 * * *$ \\
\hline $\mathrm{N}$ & 79,230 & 41,625 & 22,130 & 88,020 & 231,005 \\
\hline Urban: Never married & $0.050 * * *$ & $0.088 * * *$ & 0.002 & -0.001 & $0.053^{* * *}$ \\
\hline Married & -0.009 & -0.039 & $-0.126^{* * *}$ & $-0.134 * * *$ & $-0.093 * * *$ \\
\hline Divorced/widowed & $0.085^{* * *}$ & $0.087 * *$ & $0.084 * * *$ & $0.099 * * *$ & $0.097 * * *$ \\
\hline All & $0.020^{* *}$ & 0.006 & $0.061 * * *$ & $-0.071 * * *$ & $-0.033^{* * *}$ \\
\hline $\mathrm{N}$ & 59,068 & 45,522 & 28,082 & 57,018 & 189,690 \\
\hline \multicolumn{6}{|c|}{ Difference: FHH with Male Adult minus FHH No Male Adult } \\
\hline Rural: Never married & 0.030 & -0.125 & -0.043 & -0.048 & 0.001 \\
\hline Married & -0.022 & $-0.173 * * *$ & $-0.086^{* * *}$ & $-0.115^{* * *}$ & $-0.078 * * *$ \\
\hline Divorced/widowed & $0.031 * *$ & $-0.056^{* *}$ & $-0.147 * * *$ & $-0.107^{* * *}$ & -0.014 \\
\hline All & 0.011 & $-0.100^{* * *}$ & $-0.086^{* * *}$ & $-0.116^{* * *}$ & $-0.028 * * *$ \\
\hline $\mathrm{N}$ & 20,203 & 8,435 & 11,259 & 16,571 & 56,468 \\
\hline Urban Never married & -0.037 & -0.027 & -0.050 & $-0.052^{*}$ & $-0.036^{*}$ \\
\hline Married & $-0.091 * * *$ & -0.059 & $-0.056 * * *$ & -0.020 & $-0.057 * * *$ \\
\hline Divorced/widowed & -0.003 & -0.016 & $-0.099 * * *$ & $-0.053^{* *}$ & $-0.032 * *$ \\
\hline All & $-0.041 * * *$ & -0.035 & $-0.055^{* * *}$ & $-0.048^{* *}$ & $-0.037 * * *$ \\
\hline $\mathrm{N}$ & 17,135 & 11,245 & 11,905 & 16,571 & 54,242 \\
\hline
\end{tabular}

Note: Data are from the PovcalNet harmonized database. Statistics are FHHs - MHHs differences, and FHHs with - FHHs without a male adult differences, in average values for the headcount index, by marital status and rural/urban location. "All" refers to all households, regardless of marital status. A positive coefficient implies FHHs have a higher value of the headcount index than MHHs. Divorced includes separated. Heads that report living together with their spouse are treated as a separate (unshown) category, but are included in the All category. $\mathrm{N}$ and All rows are the same as in the first panel. * prob. $<.10 * *$ prob. $<.05 * * *$ prob. $<.01$. 
Table 8. Estimated associations between male and female headship and log expenditure per capita with various controls

\begin{tabular}{|c|c|c|c|c|c|c|c|c|c|c|c|c|}
\hline & \multicolumn{6}{|l|}{ Rural } & \multicolumn{6}{|l|}{ Urban } \\
\hline & (1) & (2) & (3) & (4) & (5) & (6) & (7) & (8) & (9) & (10) & (11) & (12) \\
\hline \multicolumn{13}{|l|}{ Regression 1} \\
\hline \multirow[t]{2}{*}{ FHH (all) } & $0.10^{* * *}$ & $0.04^{* * *}$ & $-0.13^{* * *}$ & $-0.13 * * *$ & $-0.08 * * *$ & $-0.05 * * *$ & $-0.03 * * *$ & $-0.08^{* * *}$ & $-0.17 * * *$ & $-0.16^{* * *}$ & $-0.08^{* * *}$ & $-0.01 * * *$ \\
\hline & $(23.86)$ & $(9.95)$ & $(-35.82)$ & $(-34.59)$ & $(-15.21)$ & $(-9.21)$ & $(-5.39)$ & $(-17.42)$ & $(-40.06)$ & $(-39.19)$ & $(-14.97)$ & $(-2.68)$ \\
\hline $\mathrm{N}$ & 230,873 & 198,040 & 198,040 & 198,040 & 182,639 & 182,417 & 189,679 & 157,596 & 157,596 & 157,596 & 137,155 & 136,966 \\
\hline \multicolumn{13}{|l|}{ Regression 2} \\
\hline \multirow[t]{2}{*}{ FHH, no male adult } & $0.15^{* * *}$ & $0.11^{* * *}$ & $-0.18^{* * *}$ & $-0.16 * * *$ & $-0.12 * * *$ & $-0.08^{* * *}$ & $0.07^{* * *}$ & $0.02 * * *$ & $-0.21 * * *$ & $-0.18^{* * *}$ & $-0.11 * * *$ & $-0.05^{* * *}$ \\
\hline & $(27.66)$ & $(23.18)$ & $(-40.07)$ & $(-36.91)$ & $(-20.21)$ & $(-15.16)$ & (11.11) & $(3.95)$ & $(-41.04)$ & $(-33.85)$ & $(-17.78)$ & $(-7.93)$ \\
\hline \multirow[t]{2}{*}{ FHH, male adult } & $0.03^{* * *}$ & $-0.09 * * *$ & $-0.06 * * *$ & $-0.07 * * *$ & $-0.02 * *$ & $0.02^{* *}$ & $-0.17 * * *$ & $-0.24 * * *$ & $-0.10^{* * *}$ & $-0.14 * * *$ & $-0.03 * * *$ & $0.04^{* * *}$ \\
\hline & $(4.87)$ & $(-14.83)$ & $(-10.84)$ & $(-12.25)$ & $(-2.42)$ & $(2.46)$ & $(-24.99)$ & $(-37.13)$ & $(-17.36)$ & $(-23.84)$ & $(-4.86)$ & $(5.72)$ \\
\hline $\mathrm{N}$ & 56,468 & 46,505 & 46,505 & 46,505 & 41,034 & 40,992 & 54,242 & 43,870 & 43,870 & 43,870 & 36,760 & 36,709 \\
\hline \multicolumn{13}{|l|}{ Controls } \\
\hline Country f.e. & No & Yes & Yes & Yes & Yes & Yes & No & Yes & Yes & Yes & Yes & Yes \\
\hline Household size, log & No & No & Yes & Yes & Yes & Yes & No & No & Yes & Yes & Yes & Yes \\
\hline $\begin{array}{l}\text { Demographic } \\
\text { composition }\end{array}$ & No & No & No & Yes & Yes & Yes & No & No & No & Yes & Yes & Yes \\
\hline
\end{tabular}




\begin{tabular}{|c|c|c|c|c|c|c|c|c|c|c|c|c|}
\hline Marital status & No & No & No & No & Yes & Yes & No & No & No & No & Yes & Yes \\
\hline Head age and education & No & No & No & No & No & Yes & No & No & No & No & No & Yes \\
\hline
\end{tabular}

Note: PovcalNet harmonized database. Dependent variable is log household consumption per capita. Coefficients are for two separate regressions: in the first, for an indicator for whether a household is female-headed or not; in the second: for an interaction term of female head and no adult male in the household and an interaction term for female head and adult male residing in the household. All coefficients are relative to male-headed households. Includes all households. All regressions include survey year and month fixed effects. Marital status categories are never married, divorced or separated and widowed (with married omitted). Household composition is share 0 to 14 years of age and share 65 and older (share 15 to 64 is omitted). Head's age includes age and age squared. Education consists of an indicator equal to 1 if head has at least primary, and an indicator equal to 1 if the head has at least secondary education. Robust standard errors and population weights are used. t-statistics in parentheses. $*$ prob. $<.10 * *$ prob. $<.05 * * *$ prob. $<.01$ 